\title{
Bacillus: A Biological Tool for Crop Improvement through Bio-Molecular Changes in Adverse Environments
}

\author{
Ramalingam Radhakrishnan ${ }^{1 *}$, Abeer Hashem ${ }^{2,3}$ and Elsayed F. Abd_Allah ${ }^{4 *}$ \\ ${ }^{1}$ Department of Biotechnology, Yeungnam University, Gyeongsan, South Korea, ${ }^{2}$ Botany and Microbiology Department, \\ College of Science, King Saud University, Riyadh, Saudi Arabia, ${ }^{3}$ Mycology and Plant Disease Survey Department, Plant \\ Pathology Research Institute, Giza, Egypt, ${ }^{4}$ Plant Production Department, College of Food and Agricultural Sciences, King \\ Saud University, Riyadh, Saudi Arabia
}

OPEN ACCESS

Edited by:

Wim Van den Ende,

KU Leuven, Belgium

Reviewed by:

Onur Kirtel,

Marmara University, Turkey

Mileidy Cruz-Martín,

Instituto de Biotecnolgía de las

Plantas, Cuba

Joan Combie,

Montana Polysaccharides Corp.

United States

${ }^{*}$ Correspondence:

Ramalingam Radhakrishnan ramradhakrish@gmail.com

Elsayed F. Abd_Allah

eabdallah@ksu.edu.sa

Specialty section: This article was submitted to

Plant Physiology,

a section of the journal

Frontiers in Physiology

Received: 06 July 2017

Accepted: 22 August 2017

Published: 06 September 2017

Citation:

Radhakrishnan R, Hashem A and

Abd_Allah EF (2017) Bacillus: A

Biological Tool for Crop Improvement

through Bio-Molecular Changes in

Adverse Environments.

Front. Physiol. 8:667.

doi: 10.3389/fphys.2017.00667
Crop productivity is affected by environmental and genetic factors. Microbes that are beneficial to plants are used to enhance the crop yield and are alternatives to chemical fertilizers and pesticides. Pseudomonas and Bacillus species are the predominant plant growth-promoting bacteria. The spore-forming ability of Bacillus is distinguished from that of Pseudomonas. Members of this genus also survive for a long time under unfavorable environmental conditions. Bacillus spp. secrete several metabolites that trigger plant growth and prevent pathogen infection. Limited studies have been conducted to understand the physiological changes that occur in crops in response to Bacillus spp. to provide protection against adverse environmental conditions. This review describes the current understanding of Bacillus-induced physiological changes in plants as an adaptation to abiotic and biotic stresses. During water scarcity, salinity and heavy metal accumulate in soil, Bacillus spp. produce exopolysaccharides and siderophores, which prevent the movement of toxic ions and adjust the ionic balance and water transport in plant tissues while controlling the pathogenic microbial population. In addition, the synthesis of indole-3-acetic acid, gibberellic acid and1-aminocyclopropane-1-carboxylate (ACC) deaminase by Bacillus regulates the intracellular phytohormone metabolism and increases plant stress tolerance. Cell-wall-degrading substances, such as chitosanase, protease, cellulase, glucanase, lipopeptides and hydrogen cyanide from Bacillus spp. damage the pathogenic bacteria, fungi, nematodes, viruses and pests to control their populations in plants and agricultural lands. The normal plant metabolism is affected by unfavorable environmental stimuli, which suppress crop growth and yield. Abiotic and biotic stress factors that have detrimental effects on crops are mitigated by Bacillus-induced physiological changes, including the regulation of water transport, nutrient up-take and the activation of the antioxidant and defense systems. Bacillus association stimulates plant immunity against stresses by altering stress-responsive genes, proteins, phytohormones and related metabolites. This review describes the beneficial effect of Bacillus spp. on crop plants, which improves plant productivity under unfavorable climatic conditions, and the current understanding of the mitigation mechanism of Bacillus spp. in stress-tolerant and/or stress-resistant plants.

Keywords: Bacillus, crop plants, diseases, heavy metals, drought, salinity 


\section{INTRODUCTION}

The growth and yield of crop plants depend on genetic and variable environmental factors (Kleinwechter et al., 2016; Li et al., 2016). Plant breeding and genetic transformation approaches are used to transfer desired genes from crop varieties via sexual hybridization and artificial insertion, respectively, to develop new cultivars with the desired traits, such as high yield and adaptation to unfavorable environmental conditions (Jain, 1998). There is less commercial success for genetically modified agricultural crops. Numerous microbes are naturally beneficial to plants and help to sustain plant growth and yield during abiotic and biotic stresses. Plant cell chloroplasts and mitochondria evolved from symbiotic bacteria (Martin et al., 2001), and these key organelles absorb and convert energy for plant growth and survival. Plant-beneficial bacteria and fungi, living in the soil as free organisms or as endophytes, that trigger plant growth and protect plants from diseases and abiotic factors have been well documented by several researchers (Tonelli et al., 2010; Radhakrishnan et al., 2014). Some of the bacteria belonging to the Acetobacter, Azospirillum, Azotobacter, Bacillus, Burkholderia, Klebsiella, Pseudomonas, and Serratia genera have been recorded as plant growth-promoting bacteria (PGPB) (Glick, 1995; Jones et al., 2007). Among several species of PGPB, the Pseudomonas and Bacillus spp. have been identified as the predominant communities (Kang et al., 2015a), and a few of the PGPB have been commercialized due to their survival within a diverse range of biotic and abiotic environments. The first commercial bacterial fertilizer, Alinit, was developed from Bacillus spp. and resulted in a $40 \%$ increase in crop yield (Kilian et al., 2000). Other Bacillus spp.-based products, such as Kodiak (Bacillus subtilis GB03), Quantum-400 (B. subtilis GB03), Rhizovital (Bacillus amyloliquefaciens FZB42), Serenade (B. subtilis QST713), and YIB (Bacillus spp.), have been commercialized for improving crop production (Brannen and Kenney, 1997; Ngugi et al., 2005; Cawoy et al., 2011). Indeed, Bacillus-based bio-fertilizers are more active compared to Pseudomonas-based fertilizers due to the more effective metabolite production and sporeforming character of Bacillus spp., which enhances the viability of cells in commercially formulated products (Haas and Defago, 2005).

Bacillus spp. are gram positive, ubiquitous in nature and recovered from all niches in the environment. These species have also been used to prepare medicinal, industrial and agricultural products (Lyngwi and Joshi, 2014). Bio-fertilizers can be used as alternatives to chemical fertilizers and pesticides and can provide new insights into enhancing plant growth and yield in the face of diseases (Choudhary, 2011). The plantbeneficial Bacillus spp. associate with roots or rhizospheres and develop biofilms to increase plant growth (Beauregard et al., 2013). The application of Bacillus-based fertilizers to soil can enhance the plant-available forms of nutrients in rhizospheres, control disease-causing pathogenic microbial growth and induce pest defense systems (Garcia-Fraile et al., 2015; Kang et al., 2015b). This review is focused on the growth-promoting potential of Bacillus spp. in crop plants and the involvement of these bacteria in reprogramming plant physiological changes to achieve abiotic and biotic stress tolerance.

\section{BACILLUS SPP. METABOLITES PROMOTE PLANT GROWTH}

Seed germination and plant growth are significantly influenced by the nutrients available in the soil. Plants absorb phosphorus $(\mathrm{P})$ and nitrogen $(\mathrm{N})$ from the soil through root transporters, but the bioavailable forms of $\mathrm{P}$ and $\mathrm{N}$ are limited in rhizospheres (De-Willigen, 1986; Robinson, 2001; Bidondo et al., 2012). The beneficial effect of Bacillus spp. to crop improvement is given in Table 1. Bacillus spp. convert the complex form of essential nutrients, such as $\mathrm{P}$ and $\mathrm{N}$, to a simple available form that is used during uptake by plant roots (Kang et al., 2015a; Kuan et al., 2016). Phosphate is involved in nucleic acid, phospholipid, and adenosine triphosphate (ATP) metabolism, among other metabolic pathways, in plant cells (Theodorou and Plaxton, 1993). The secretion of phosphatases and organic acids from Bacillus spp. acidifies the surrounding environment to facilitate the conversion of inorganic phosphate into free phosphate (Kang et al., 2014a, 2015a). Additionally, $\mathrm{N}$ is an important component of proteins, nucleic acids and other organic compounds in plants, and the available form of $\mathrm{N}$ in soil is limited, which slows plant growth in natural habitats (Barker et al., 1974; DeWilligen, 1986). Some of the Bacillus spp. release ammonia from nitrogenous organic matter (Hayat et al., 2010). Ding et al. (2005) reported that some of the Bacillus spp. have the nifH gene and produce nitrogenase (EC 1.18.6.1), which can fix atmospheric $\mathrm{N}_{2}$ and provide it to plants to enhance plant growth and yield by delaying senescence (Kuan et al., 2016).

The iron-chelating properties of Bacillus spp. via siderophore production help to solubilize iron from minerals and organic compounds in rhizospheres (Nadeem et al., 2012). Siderophores bind $\mathrm{Fe}^{3+}$ in complex substances and reduce the $\mathrm{Fe}^{3+}$ to $\mathrm{Fe}^{2+}$, which then enters plants (Walker and Connolly, 2008).

The presence of tryptophan and other bacterial food source compounds induces the synthesis of indole-3-acetic acid (IAA) and other hormones in bacterial populations (Glick, 2014). Plant-growth-promoting substances, such as IAA, gibberellins, cytokinins and spermidines, are synthesized by Bacillus spp. and increase root and shoot cell division and elongation (Arkhipova et al., 2005; Xie et al., 2014; Radhakrishnan and Lee, 2016). The secretion of ACC deaminase (EC 4.1.99.4) by Bacillus spp. inhibits ethylene synthesis in crop plants and promotes plant growth (Xu M. et al., 2014; Pourbabaee et al., 2016). ACC deaminase breaks down ACC into ammonia and ketobutyrate in plant cells, and the cross-talk between ACC deaminase and IAA facilitates the reduction of ethylene, thereby enhancing plant growth (Honma and Shimomura, 1978; Glick, 2014). The $\mathrm{N}$ fixation, $\mathrm{P}$ solubilization, plant growth promoting hormones and enzymes section of Bacillus spp. confirm their biofertilizer effects on plants to improve the growth and yield of crops. 
TABLE 1 | Bio-fertilizer effect of Bacillus spp. on crop plants.

\begin{tabular}{|c|c|c|}
\hline Bacillus species & Plant growth promotion & References \\
\hline B. insolitus; B. subtilis; B. methylotrophicus & $\begin{array}{l}\text { Increase the length and biomass of shoot, roots and } \\
\text { leaves }\end{array}$ & $\begin{array}{l}\text { Ashraf et al., 2004; Barnawal et al., 2013; Radhakrishnan and } \\
\text { Lee, } 2016\end{array}$ \\
\hline B. megaterium; B. subtilis & Enhance fruits and grains yield & Kilian et al., 2000; Dursun et al., 2010 \\
\hline B. pumilus; B. megaterium & $\begin{array}{l}\text { Solubilize the } \mathrm{P} \text { and fix the } \mathrm{N} \text { in soil and increase } \\
\text { their transport to roots }\end{array}$ & Kang et al., 2014a; Kuan et al., 2016 \\
\hline B. subtilis; B. methylotrophicus & $\begin{array}{l}\text { Synthesis of plant growth hormones (IAA, GAs, } \\
\text { cytokinins and spermidines) trigger plant growth }\end{array}$ & $\begin{array}{l}\text { Arkhipova et al., 2005; Xie et al., 2014; Radhakrishnan and } \\
\text { Lee, } 2016\end{array}$ \\
\hline B. subtilis; B. mojavensis & $\begin{array}{l}\text { Secretes ACC deaminase to inhibit plant } \\
\text { senescence }\end{array}$ & Xu M. et al., 2014; Pourbabaee et al., 2016 \\
\hline B. megaterium; B. methylotrophicus & $\begin{array}{l}\text { Enhance the endogenous proteins, amino acids, } \\
\text { sugars, photosynthetic pigments and minerals ( } \mathrm{K} \text {, } \\
\mathrm{Mg}, \mathrm{Na}, \mathrm{P}, \mathrm{Fe}, \mathrm{Zn} \text {, and } \mathrm{N} \text { ) in plants }\end{array}$ & Kang et al., 2014a; Radhakrishnan and Lee, 2016 \\
\hline
\end{tabular}

\section{BACILLUS-MEDIATED PLANT GROWTH PROMOTION UNDER ABIOTIC STRESS CONDITIONS}

\section{Plant Drought Tolerance by Bacillus spp. Inoculation}

Soil moisture severely influences crop productivity in arid and semiarid areas. Low moisture content in the soil due to low annual precipitation creates drought stress in plants. Regulating the uptake and distribution of nutrients, transport of water, and accumulation of compatible solutes and antioxidants in plant tissues can help to improve plant productivity under drought conditions (Boomsma and Vyn, 2008). Applying droughttolerant Bacillus spp. to the soil increases the populations of these bacteria on the roots and stimulates root exudation to promote both bacterial and plant growth (Sandhya et al., 2011). Plants colonized by Bacillus spp. take up more water, which is an important mechanism for plant protection against droughtinduced damage (Marulanda et al., 2009). The mitigating effects of Bacillus-induced physiological changes in plants are shown in Figure 1 and Table 2.

The uptake of $\mathrm{N}, \mathrm{P}$, and potassium $\left(\mathrm{K}^{+}\right)$decreases in droughtinjured plants, whereas treatments with Bacillus spp. increase these macro nutrients in stressed plants (Barnawal et al., 2013). Bacterial enzymes increase the accumulation of the bioavailable forms of these macro nutrients in the soil and plants (Kang et al., 2015a; Kuan et al., 2016). In addition, these bacteria regulate high-affinity potassium transporter 1 (HKT1), which modulates $\mathrm{Na}^{+} / \mathrm{K}^{+}$homeostasis, to mitigate drought stress (Gassmann et al., 1996; Vieira-Pires et al., 2013). Furthermore, $\mathrm{K}^{+}$plays a key role in stomatal opening, turgor pressure maintenance, osmotic balance and controlling the transpiration rate in plants under drought stress (Loutfy et al., 2012). The scavenging activity of $\mathrm{K}^{+}$ helps to inhibit reactive oxygen species (ROS) formation during photosynthesis and NADPH oxidase metabolism (Cakmak, 2005). The concentrations of plant nutrients, such as $\mathrm{Ca}^{++}$, $\mathrm{Mg}^{++}, \mathrm{Zn}^{++}, \mathrm{Mn}^{++}$, and $\mathrm{Cu}^{++}$, are increased by Bacillus megaterium, Bacillus thuringiensis and Bacillus spp. applications in drought-stressed lavandula (Lavandula angustifolia L.) and salvia (Salvia divinorum L.) plants (Armada et al., 2014). $\mathrm{Ca}^{++}$is

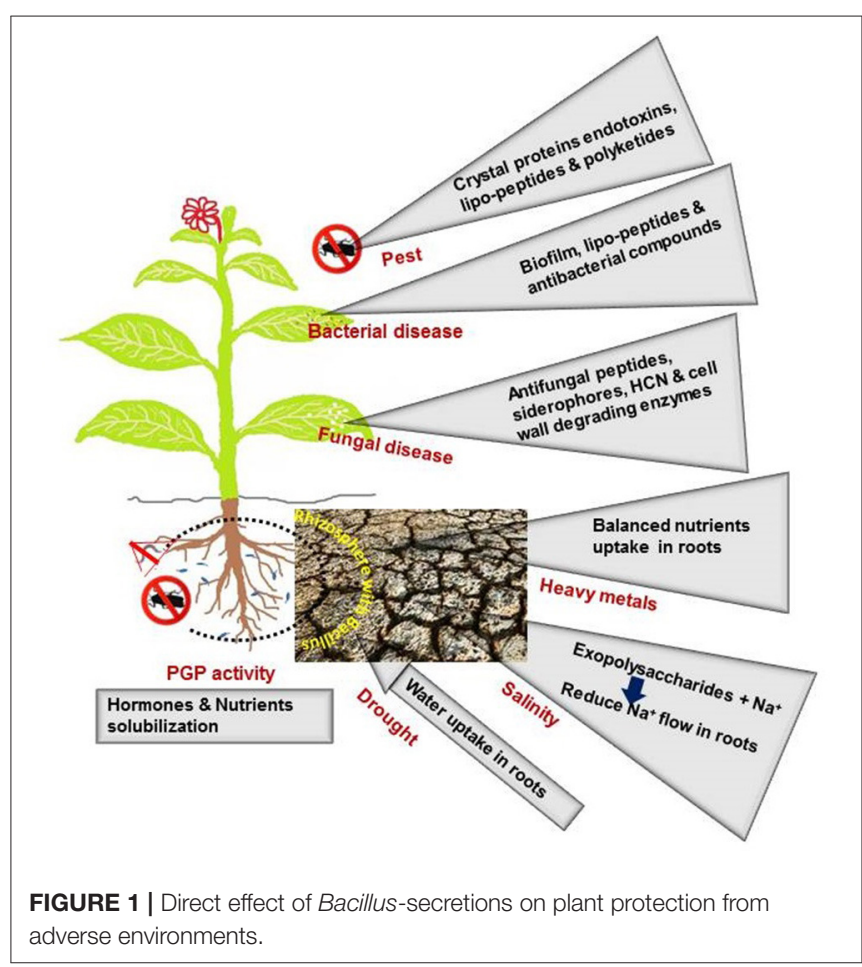

involved in stabilizing membrane systems, and the accumulation of $\mathrm{Mg}^{++}$regulates the homeostasis of ions in the chloroplasts, vacuoles and stomata of plant tissues (Shaul-Keinan et al., 2002; Huda et al., 2013). Some Bacillus spp., enhance plant growth during drought stress by increasing Fe levels. The high level of $\mathrm{Fe}^{++}$in plants is probably due to siderophores derived from Bacillus spp. (Zawadzka et al., 2009). Aquaporins, particularly those encoded by the plasma membrane intrinsic protein (PIP) subfamily of aquaporin genes (Maurel et al., 2008), offer a lowresistance pathway for the movement of water across membranes to compensate for drought effects. Bacillus spp. regulate all the PIP genes to increase the hydraulic conductivity of roots in drought stressed plants, and aquaporins also transport urea, $\mathrm{CO}_{2}$ and $\mathrm{H}_{2} \mathrm{O}_{2}$ for $\mathrm{N}$ metabolism, carbon fixation and stress signaling, respectively (Armada et al., 2015). 
TABLE 2 | Bacillus-induced physiological and biochemical changes in crop plants during drought, salinity and heavy metal accumulation in soil and pest, pathogenic bacterial and fungal infection.

\begin{tabular}{|c|c|c|c|}
\hline Stress factors & \multicolumn{2}{|c|}{ Plant functions } & References \\
\hline & $\begin{array}{l}\text { Reduce plant growth } \\
\text { Decrease the water, nutrients (N, P, K, } \\
\mathrm{Ca}, \mathrm{Mg}, \mathrm{Zn}, \mathrm{Cu}, \mathrm{Mn} \text {, and } \mathrm{Fe} \text { ) and } \\
\text { pigments } \\
\text { Up or down regulate the antioxidants } \\
\text { (CAT, SOD, POD, APX, and GR), } \\
\text { hormones (SA, JA, and ABA) and } \\
\text { drought responsible genes }\end{array}$ & $\begin{array}{l}\text { Enhance plant growth } \\
\text { Increase the water, nutrients (N, P, K, Ca, } \\
\mathrm{Mg}, \mathrm{Zn}, \mathrm{Cu}, \mathrm{Mn} \text {, and Fe), pigments and } \\
\text { hormones (SA, JA, and ABA). } \\
\text { Up or down regulate the antioxidants } \\
\text { (CAT, SOD, POD, APX, and GR) and } \\
\text { drought responsible genes }\end{array}$ & $\begin{array}{l}\text { Marulanda et al., 2009; Jumali et al., 2011; } \\
\text { Barnawal et al., 2013; Castillo et al., 2013; } \\
\text { Kasim et al., 2013; Armada et al., 2014, } \\
\text { 2015; Timmusk et al., 2015; Kakar et al., } \\
2016\end{array}$ \\
\hline \multicolumn{4}{|l|}{ SOIL SALINITY } \\
\hline & $\begin{array}{l}\text { Reduce plant growth } \\
\text { Decrease the water, nutrients ( } \mathrm{N}, \mathrm{P}, \mathrm{K} \text {, } \\
\mathrm{Ca}, \mathrm{Mg}, \mathrm{S}, \mathrm{Mn}, \mathrm{Cu} \text {, and } \mathrm{Fe} \text { ), antioxidants } \\
\text { (CAT and POD), pigments and hormones } \\
\text { (IAA and } \mathrm{GA}) \text {. } \\
\text { Increase the } \mathrm{Na}, \mathrm{Cl}, \mathrm{ABA} \text {, and caspase } \\
\text { activity; } \mathrm{Up} \text { or down regulate the salt } \\
\text { stress responsible genes }\end{array}$ & $\begin{array}{l}\text { Enhance plant growth } \\
\text { Increase the water, nutrients (N, P, K, Ca, } \\
\mathrm{Mg}, \mathrm{S}, \mathrm{Mn}, \mathrm{Cu} \text {, and Fe), antioxidants } \\
\text { (CAT and POD), pigments and hormones } \\
\text { (IAA and GA). } \\
\text { Decrease the } \mathrm{Na}, \mathrm{Cl}, \mathrm{ABA} \text { and caspase } \\
\text { activity; Up or down regulate the salt } \\
\text { stress responsible genes }\end{array}$ & $\begin{array}{l}\text { Ashraf et al., 2004; Jha and Subramanian, } \\
\text { 2012; Mohamed and Gomaa, 2012; } \\
\text { Karlidag, 2013; Nautiyal et al., 2013; } \\
\text { Qurashi and Sabri, 2013; Kang et al., } \\
\text { 2014b }\end{array}$ \\
\hline \multicolumn{4}{|c|}{ HEAVY METALS } \\
\hline & $\begin{array}{l}\text { Reduce plant growth } \\
\text { Decrease the water, nutrients (P, Ca, Fe, } \\
\mathrm{Mn}, \mathrm{Zn}, \mathrm{Cu}, \mathrm{Cd} \mathrm{Cr} \text {, and } \mathrm{Pb} \text { ) and pigments } \\
\text { Up or down regulate the antioxidants } \\
\text { (SOD, POD, APX, and DHAR) }\end{array}$ & $\begin{array}{l}\text { Enhance plant growth } \\
\text { Increase the water, nutrients (P, Ca, Fe, } \\
\mathrm{Mn}, \mathrm{Zn}, \mathrm{Cu}, \mathrm{Cd} \mathrm{Cr} \text {, and } \mathrm{Pb} \text { ) and pigments } \\
\text { Up or down regulate the antioxidants } \\
\text { (SOD, POD, APX, and DHAR) }\end{array}$ & $\begin{array}{l}\text { Wani and Khan, 2010; Malekzadeh et al., } \\
\text { 2012; Gururani et al., 2013; Wang et al., } \\
\text { 2013; Jamil et al., } 2014\end{array}$ \\
\hline \multicolumn{4}{|l|}{ PEST } \\
\hline & $\begin{array}{l}\text { Increase the larval population } \\
\text { Reduce or stimulate the JA, ISR, and } \\
\text { allelochemicals }\end{array}$ & $\begin{array}{l}\text { Decrease the larval population } \\
\text { Enhance the JA, ISR, and allelochemicals }\end{array}$ & $\begin{array}{l}\text { Ben-Khedher et al., 2015a; Arrizubieta } \\
\text { et al., 2016; Boukedi et al., 2016; Gadhave } \\
\text { and Gange, 2016; Zebelo et al., } 2016\end{array}$ \\
\hline
\end{tabular}

The limited uptake of water and nutrients disturbs the normal cellular physiological processes and generates ROS, which damage proteins, lipids and nucleic acids in drought-exposed plants (Zgallai et al., 2005; Miller et al., 2010). ROS accumulation affects lipid membranes and causes lipid peroxidation and enhanced electrolyte leakage. Recovery from oxidative stressinduced damage is possible via antioxidant synthesis, which inhibits ROS formation. Bacillus-based bacterial association in plants can reduce the synthesis of ROS in cells via various scavenging enzymes (Kakar et al., 2016). Bacillus spp. either increase or decrease antioxidant enzyme activities in plants to mitigate drought stress. For example, B. safensis increases catalase (CAT; EC 1.11.1.6), superoxide dismutase (SOD; EC 1.15.1.1), peroxidase (POD; EC 1.11.1.7), ascorbate peroxidase (APX; EC 1.11.1.11) and glutathione reductase (GR; EC 1.6.4.2) activities (Chakraborty et al., 2013), while B. amyloliquefaciens decreases APX, GR and dehydroascorbate reductase (DHAR; 1.8.5.1) activities in plants under drought stress (Kasim et al., 2013).

The drought-induced oversynthesis of proline is suppressed in bacteria-treated plants, reflecting bacterial-derived resistance to the detrimental effects induced by drought (Barnawal et al., 2013). The normal metabolism of carbohydrates and amino acids is disturbed in plants during drought stress, and this effect is 
possibly reversed by interactions with Bacillus spp. Sucrose and fructose concentrations are enhanced in plants to contribute to drought adaptation by increasing root growth (Gagne-Bourque et al., 2016). As a consequence of stress, some of the endogenous amino acid accumulation triggers the production of secondary metabolites in stress-affected plants to mitigate oxidative stress (Jia et al., 2001). The synthesis of aromatic, glutamic and aspartic amino acid families is greater in plants associated with Bacillus spp. Histidine, tyrosine, phenylalanine, valine, leucine, isoleucine, asparagine, serine and $\gamma$-aminobutyric acid levels are increased due to the effects of drought in soil (Gagne-Bourque et al., 2016).

Drought inhibits pigment synthesis and reduces photosynthesis, while Bacillus spp. stimulate the synthesis of chlorophylls a and b and carotenoid in stressed plants, which increases photosynthesis (Barnawal et al., 2013; Hashem et al., 2015). The modulation of plant hormonal signals reprograms plant growth during drought stress. The hormone- and ACC deaminase-producing Bacillus spp. regulate plant growth by enhancing levels of stress-related hormones, such as salicylic acid (SA), jasmonic acid (JA) and abscisic acid (ABA), and reducing ACC, which is responsible for generating ethylene (Barnawal et al., 2013; Castillo et al., 2013). ABA accumulation improves drought tolerance by activating antioxidant enzymes and prevents water loss by stomatal closure (Lu et al., 2009; Zhu et al., 2011). Similarly, SA induces the expression of stressrelated genes to maintain membrane stability and prevent the accumulation of ROS (El-Tayeb, 2005; Jumali et al., 2011).

The normal gene expression pattern in plants is altered during drought. The expression of OsDIL (drought-induced lipid transfer protein), OsDREB1A (dehydration-responsive element-binding protein 1A), OsGAPDH (glyceraldehyde-3phosphate dehydrogenase), OsWRKY11 (WRKY transcription factor 11), $P 4 H$ (prolyl-4-hydroxylase), Cadhn (dehydrin-like protein), VA (vacuolar $\mathrm{H}^{+}$-ATPase), sHSP (small heat shock protein), CaPR-10 (pathogenesis-related protein 10), $c A P X$ (cytosolic ascorbate peroxidase), $r b c L$ (ribulose-1,5-bisphosphate carboxy/oxygenase large subunit) and $r b c S$ (ribulose-1,5bisphosphate carboxy/oxygenase small subunit) genes are affected during drought stress in crop plants. The lipid transfer is essential for development of lipidic orbicules and pollen exine formation, which is initiated by OsDIL genes (Zhang et al., 2010). DREB proteins involves in ABA-dependent and independent pathways to enhance the stress tolerance (Lata and Prasad, 2011). Similarly, GAPDH gene participates in cell proliferation, regulation of telomere length, apoptotic pathway and DNA repair (Kosova et al., 2017). WRKY 11 gene induces systemic resistance through JA/ethylene mediated metabolic pathway (Jiang et al., 2016). However, $P 4 H$ is responsible for hydroxylating proline-rich peptides influencing carbohydrate, lipid, protein and DNA metabolisms during plant growth and development (Asif et al., 2009). DHN genes confer stress tolerance due to the structural stabilization with chaperon-like activity to protect the macromolecules in cells (Koag et al., 2003; Porat et al., 2004). The $\mathrm{pH}$ is a fundamental factor for biological processes. Vacuolar $\mathrm{H}^{+}$-ATPase regulates the $\mathrm{pH}$ of cells, which results to stabilize the membrane, protein degradation, transport of small molecules and several metabolisms (Forgac, 2007). During heat and osmotic stresses, $s H S P$ genes are expressed to conserve the metabolic reactions in cells (Schoffl et al., 1998). $P R-10$ genes initiate and reprogramme the protein synthesis in pathogen infected or abiotic stress exposed plants (Xu P. et al., 2014). An antioxidant stimulating gene, $A P X$ plays a major role in redox condition of the electron transport machinery of chloroplast by regulating $\mathrm{H}_{2} \mathrm{O}_{2}$ levels (Davletova et al., 2005). In addition, $r b c L$ and $r b c S$ genes drive the synthesis of Rubisco enzymes for $\mathrm{CO}_{2}$ fixation during photosynthesis (Andersson and Backlund, 2008).

Some studies have revealed that tolerance against drought in bacteria-treated plants is associated with higher gene expression levels of OsDIL, OsDREB1A, OsGAPDH, OsWRKY11, P4H, Cadhn, VA, sHSP, CaPR-10, cAPX, rbcL, and rbcS gene expression (Khan et al., 2011; Wang et al., 2012; Kasim et al., 2013; Lim and Kim, 2013; Timmusk et al., 2015) and lower gene expression levels of APX1 (ascorbate peroxidase 1), SAMS1 (S-adenosylmethionine synthetase 1 , which acts as methyl donor and a precursor to polyamines synthesis (Sofia et al., 2001) and HSP17.8 (heat shock protein 17.8) gene expression (Kakar et al., 2016). Plant drought tolerance may be accomplished by the interaction with Bacillus spp. resulting in enhanced water uptake, transport of nutrients, synthesis of hormones and pigments, and by the regulation of drought stress related genes and enzymes.

\section{Bacillus spp. Applications to Improve Plant Health in Saline Soil}

Climatic changes in the environment affect regular rainfall each year. Salinity in agricultural land has been spreading worldwide due to low rainfall, high water evaporation rates and improper irrigation practices (Al-Karaki, 2006). The accumulation of salt in soil reduces the soil water potential and affects water and nutrient uptake by plant roots (Porcel et al., 2012). Under conditions of salinity, crop plants face disorder in several metabolic pathways, such as those related to photosynthesis, respiration, redox system homeostasis, phytohormone regulation, and carbohydrate and amino acid synthesis, which leads to reduced seed germination, plant growth and yield (Munns and Tester, 2008; Rady, 2011; Radhakrishnan and Lee, 2013, 2014). A microbial inoculation that includes Bacillus spp. can enhance plant growth during salt stress, which is an eco-friendly approach to sustainable agriculture (Radhakrishnan et al., 2014; Hashem et al., 2015, 2016a,b). The multiple plant growth-promoting characteristics (phosphate solubilization, ammonia, IAA and siderophore production) of Bacillus licheniformis A2 mitigate the detrimental effects of salt stress and increase plant growth in stressed peanut plants (Goswami et al., 2014). The association of Bacillus spp. with plants alters the plant metabolism in stressed plants to increase plant growth (Table 2). To tolerate salt stress, plants must prevent the excess uptake of $\mathrm{Na}^{+}$and $\mathrm{Cl}^{-}$, but they need to continue the uptake of essential nutrients, such as $\mathrm{K}^{+}$and $\mathrm{NO}_{3}^{-}$(Jeschke and Wolf, 1988). Exopolysaccharide (EPS) in the rhizosphere soil binds $\mathrm{Na}^{+}$and inhibits $\mathrm{Na}^{+}$transport into plant root cells (Figure 1). Inoculating wheat seedlings with EPSproducing Bacillus insolitus MAS17 and certain other Bacillus 
spp. covers the root zones with soil sheaths and restricts the passive flow of $\mathrm{Na}^{+}$into the stele to mitigate salt stress effects (Ashraf et al., 2004). The bacteria-induced enhancement of the $\mathrm{K}^{+} / \mathrm{Na}^{+}$ratio in plants grown in saline soil mitigates the effects of salinity stress (Han et al., 2014). The elevated levels of N, P, $\mathrm{K}, \mathrm{Ca}, \mathrm{Mg}, \mathrm{S}, \mathrm{Mn}, \mathrm{Cu}$, and $\mathrm{Fe}$ produced in salt-affected plants by the interaction with Bacillus spp. maintains plant growth during stress (Jha and Subramanian, 2012; Karlidag, 2013). The salt-tolerant bacteria increase the relative water content as well as the osmotic and turgor potential to improve the growth of salt-injured plants (Yang et al., 2016).

Bacillus spp. reduce the toxic effects of salinity in plants by inhibiting lipid peroxidation (Han et al., 2014). Hashem et al. (2015) proved that B. subtilis improved lipid synthesis, specifically that of oleic, linoleic, and linolenic acids as well as phospholipids, in plants grown under salt stress. This increase in lipid synthesis might mitigate lipid peroxidation and oxidative stress in the plants. ROS production is controlled by antioxidant enzymes. In bacteria-treated plants, APX and SOD activities are decreased, while nitrate reductase (NR; EC 1.7.1.1), CAT and POD activities are enhanced (Jha and Subramanian, 2012, 2015). Bacillus pumilus associated with the roots of saltstressed rice plants reduces the activity of caspase (Jha and Subramanian, 2014), which is a protease that belongs to the cysteine endopeptidase family and is involved in programmed cell death in plants (Groten et al., 2006). The reduction of caspase activity decreases ROS formation and programmed cell death and reprograms the action of antioxidants to accomplish plant tolerance (Jha and Subramanian, 2014). Salttolerant B. subtilis $\mathrm{RH}-4$ improves seed germination and plant growth by enhancing the synthesis of photosynthetic pigments, carbohydrates, proteins and osmolytes, such as proline, glycine betaine and choline, in salt-injured chickpea plants (Qurashi and Sabri, 2013). The regulation of these primary metabolic pathways in plants to protect against salinity-induced disorders promotes crop tolerance. In addition, some of the secondary metabolites, such as gallic acid, caffeic acid, syringic acid, vanillic acid, ferulic acid, cinnamic acid, and quercetin, are increased in plants associated with bacteria, which allows plants to tolerate salt stress (Tiwari et al., 2011).

The regulation of hormones under stress conditions is a complex phenomenon. Hormone levels are up- or downregulated by environmental factors. ABA accumulation in plants grown under salt stress induces stomatal closure to reduce water loss and increases salt tolerance via stress responsive genes (Leung and Giraudat, 1998; Herrera-Medina et al., 2007), while bacterial inoculation decreases the stress-induced ABA synthesis and protects plants from the effects of stress (Kang et al., 2014b). Similarly, Bacillus spp. can produce plant hormones to enhance the concentrations of IAA and GA but reduce the synthesis of ABA in plants grown under salt stress (Mohamed and Gomaa, 2012). Several gene families are affected by salinity, and their transcriptional disorder retards plant growth. However, bacteria stimulate the expression of the NADP-Me2 (NADP malic enzyme 2), EREBP (ethylene-responsive element-binding protein), SOSI (salt overly sensitive 1), BADH (betaine aldehyde dehydrogenase) and SERK1 (somatic embryogenesis receptor-like kinase 1) genes, while the GIG (gigantea) and SAPK4 (serine threonine protein kinase) genes in plants are down-regulated due to salinity (Nautiyal et al., 2013). Overall reports suggest that plants can tolerate soil salinity by the effect of Bacillus spp. induced regulation of several genes, proteins, antioxidant enzymes, pigments, hormones, nutrient transport and prevention of excess sodium transport in plant system.

\section{The Influence of Bacillus spp. on Plant Growth during Heavy Metal Accumulation in Soil}

Agricultural lands contaminated with trace metals deposited from industrial effluents and agro-chemicals affect the ecological food chain, including crop cultivation, and alter microbial communities (Hu et al., 2009; Ashraf et al., 2017). Accumulated $\mathrm{Cu}, \mathrm{Mn}$, and $\mathrm{Zn}$ are considered major pollutants in soil and water, and these metals cannot be easily degraded into harmless substances (Ma et al., 2009; Arthur et al., 2012). Chelators are used to reduce metal toxicity but are also harmful to living organisms (Tandy et al., 2006). In contrast, microorganisms solubilize or convert toxic metals to non-toxic forms, which is applicable to the integrated management of heavy metal phytoremediation (Bosecker, 1997; Kang et al., 2015c). The inoculation of Bacillus spp. into heavy metal-contaminated soil can possibly reduce the toxic effects of these metals on plant growth. The bacteria support plant growth by increasing water uptake and reducing electrolyte leakage to mitigate $\mathrm{Cd}$ stress (Ahmad et al., 2014). B. licheniformis enhances $\mathrm{Cu}, \mathrm{Zn}, \mathrm{Cd}, \mathrm{Cr}$ and $\mathrm{Pb}$ accumulation and distribution in plants grown in heavy metal-contaminated soil, which leads to reduced levels of toxic metals in soil (Brunetti et al., 2012). Similarly, excess amounts of $\mathrm{Cd}$ in soil reduce nutrient ( $\mathrm{P}, \mathrm{Fe}, \mathrm{Zn}$, and $\mathrm{Mn}$ ) uptake in plants, but bacteria promote an increase in the levels of these nutrients in plants to protect against the effect of Cd (Malekzadeh et al., 2012 and Figure 1). The association of some Bacillus spp. increases the $\mathrm{P}$ and $\mathrm{Ca}$ contents and reduces $\mathrm{Ni}$ accumulation in plants grown in contaminated soil (Jamil et al., 2014). The beneficial effects of the interaction with Bacillus spp. (enhancement of water, ions, pigments and enzymes) in heavy metal-affected plants are shown in Table 2.

Heavy metal deposition in soil affects the redox state of plant metabolism by inducing signaling molecules such as ROS. Excess ROS generation damages lipid membranes and causes lipid peroxidation (Kang et al., 2015c). The contamination of soil with the most common industrial toxic metals, $\mathrm{Pb}$ and $\mathrm{As}$, accelerates lipid peroxidation in affected plants. Bacillus spp. alleviate this stress effect by reducing lipid peroxidation and SOD activity and increasing amylase and protease to promote plant growth in heavy metal-polluted soil (Pandey et al., 2013). Similarly, bacteria support plant tolerance against $\mathrm{Zn}$ and $\mathrm{Cu}$ stress by enhancing the activities of ROS scavenging enzymes, such as POD, SOD, CAT, APX, and DHAR (Gururani et al., 2013; Wang et al., 2013). Cr stress reduces acid phosphatase activity in plants, but bacterial treatment elevates the activity of this enzyme (Riaz et al., 2010). The regulation of antioxidants in cells inhibits oxidative stress damage and triggers plant growth-promoting substances 
to enable plants to adapt to metal stress. Bacillus-mediated plant tolerance against $\mathrm{Ni}$ and $\mathrm{Cr}$ stresses is achieved through the enhancement of photosynthetic pigments and leghemoglobin, which leads to increased crop yield (Wani and Khan, 2010; Jamil et al., 2014). The plant growth and survival at heavy metal polluted soil can be achieved by increasing the balanced uptake of mineral nutrients and pigments synthesis, and also modulating the endogenous antioxidants due to the association of Bacillus spp. To understand the mitigation mechanisms of Bacillus spp. against heavy metal pollution, more plant physiological studies are required.

\section{MITIGATION OF BIOTIC STRESSES IN PLANTS BY BACILLUS SPP. INOCULATION}

\section{Bacillus-Induced Pest Control and Plant Protection}

In organic farming, the use of bacterial agents is considered an environmentally friendly and safe method to increase crop productivity in the presence of pests (Dihazi et al., 2012). Plantbeneficial Bacillus spp. reduce the use of chemical fertilizers and pesticides for the sustainable production of various crops in modern agriculture (Myresiotis et al., 2015). For example, thiamethoxam is an insecticide used to control an extensive range of pests, such as aphids, beetles, lepidopteran species, thrips and whiteflies (Karmakar and Kulshrestha, 2009), but this compound causes a decline in insects beneficial to plants, such as honey bees; therefore, the use of this chemical in seed coating has been banned by the European Union (Girolami et al., 2009). Alternatively, eco-friendly microbial pesticides can fill the gap formed by the discontinuation of chemical pesticides use in the field of agriculture. A well-known bio-insecticide, $B$. thuringiensis, can control a broad range of diverse insects for pest management in the agricultural field (Navon, 2000). For example, the insects Helicoverpa armigera, Spodoptera littoralis, Oryzophagus oryzae, Spodoptera frugiperda, and Chilo partellus are damaging to plant growth and fruit, but $B$. thuringiensis inhibits the larval growth of insects and increases plant growth and yield (Brownbridge, 2001; Berlitz et al., 2012; BenfarhatTouzri et al., 2014; Arrizubieta et al., 2016) without affecting other microbial populations within the phyllosphere (Wang et al., 2014). Some other Bacillus spp., such as B. cereus, B. subtilis, and B. amyloliquefaciens, are also involved in pest control (Gadhave and Gange, 2016).

The mechanism of Bacillus-induced pest control in plants varies with pest species as well as plant genotype (Navon, 2000; Paramasiva et al., 2014; Mnif and Ghribi, 2015; Wielkopolan and Obrepalska-Steplowska, 2016). Bacillus spp. kill pest larvae and induce systemic resistance in plants (Table 2). Pesticideproducing Bacillus spp. in soil and roots support plant growth and increase the uptake and systemic translocation of pesticide (thiamethoxam) throughout the entire plant to control pest infestations (Myresiotis et al., 2015). Bacillus spp. colonize plant parts, including the phyllosphere, and larvae and/or adult pests ingest the Bacillus-containing plant tissues during feeding. A primary site of bacterial infection begins with extensive damage to the larval midgut epithelium by bacterial crystal proteins, which interact with chitin and peritrophic membranes (Vachon et al., 2012; Feng et al., 2015; Figure 1). During later stages of infection, Bacillus spp. crystal protein endotoxin, lipopeptides and polyketides (iturin, fengycin, surfactin, bacillomycin, bacillaene, macrolactin, and difficidin) modify the vacuolization of the cytoplasm, induce vesicle formation, lyse brush border membrane, and degenerate apical membranes, leading to damage of microvilli and finally causing larval death (Ben-Khedher et al., 2015a; Boukedi et al., 2016). Surfactin attaches to the $\mathrm{Ca}^{2+}$ receptor site and changes the peptide composition in the cellular phospholipid bilayer (MagetDana and Ptak, 1995), while iturin increases cell membrane permeability via the formation of ion-conducting pores (MagetDana and Peypoux, 1994). Bacillus spp. elicit the JA-pathwayrelated genes and simultaneously increase the gene expression for other secondary metabolites (allelochemicals, which inhibit pest larval growth) in plants to defend against pests (Zebelo et al., 2016). The obtained reports suggest that Bacillus spp. control the larval population of pest and trigger the ISR mechanism and allelochemicals in plants to prevent the pest damage.

\section{Bacterial Disease Prevention in Plants by the Application of Bacillus spp.}

Plant disease-causing pathogenic bacteria, fungi, viruses and nematodes are major challenges in maintaining plant health and yield in agricultural lands (Hussey and McGuire, 1987; Guo et al., 2013; Narasimhan and Shivakumar, 2015). The application of plant-beneficial microorganisms is an alternative to chemical fungicides, bactericides and nematicides and an effective environmentally friendly approach to improving plant growth and controlling many plant diseases (Choudhary and Johri, 2009; Radhakrishnan et al., 2013; Adam et al., 2014; Egamberdieva et al., 2014). Bacillus spp. inhibit pathogenic microbial growth in soil and/or in plant tissues as well as the detrimental effects of the pathogens in plants. For example, pathogenic bacteria such as Ralstonia solanacearum, Pseudomonas savastanoi and Xanthomonas axonopodis infect plants and generate diseases, whereas Bacillus spp. inoculation suppresses pathogen growth and protects plants from diseases (Krid et al., 2012; Yi et al., 2013). Biofilm formation around the root surface by Bacillus spp. and their secretion of toxins (surfactin, iturin, macrolactin, bacillomycin, and fengycin) destroy the pathogenic bacterial populations and reduce disease incidence in plants (Chen et al., 2013; Huang et al., 2014; Elshakh et al., 2016; Hinarejos et al., 2016; Figure 1). The secretions of Bacillus spp. degrade the pathogenic bacterial cell walls and change the cell morphology to kill the pathogen (Elshakh et al., 2016).

In addition, pathogenic bacteria, including $R$. solanacearum and Xanthomonas oryzae, affect plant defense systems by decreasing phenylalanine ammonia-lyase (PAL; EC 4.3.1.24), POD, PPO, SOD, CAT, and lipoxygenase (LOX; EC 1.13.11) activities, but these defense enzyme activities are accelerated in diseased plants following the administration of Bacillus spp. (Chithrashree et al., 2011; Almoneafy et al., 2013; Kurabachew and Wydra, 2014; Table 2). PAL is involved in the 
biosynthesis of polyphenol compounds (lignin, flavonoids and phenylpropanoids) and triggering the plant resistance against environmental stimuli (Fritz et al., 1976; Tanaka et al., 1989). However, the systemic resistance to diseases induced in plants by Bacillus spp. is made possible by increasing SA content and the gene and protein expression of proteinase inhibitor II (Pin2) and pathogen resistant 1 (PR1) (Jiang et al., 2015; Fousia et al., 2016; Hinarejos et al., 2016).

\section{Effects of Bacillus spp. Inoculation on Crop Protection from Pathogenic Fungi}

The antagonistic activity of Bacillus spp. controls the mycelial growth of fungi, preventing plant fungal disease (Abdalla, 2015; Chowdhury et al., 2015a; Akram et al., 2016; Aydi-Ben-Abdallah et al., 2016) and increasing plant growth and yield (Narasimhan and Shivakumar, 2015). Populations of Bacillus spp. can be successfully established in the soil and root rhizospheres without any lasting effects on other bacterial populations (Chowdhury et al., 2015a). Bacillus spp. attach to the mycelial cell walls, and the chitosanase (EC 3.2.1.123), protease (EC 3.4.21.112), cellulase (EC 3.2.1.4), glucanase (EC 3.2.1.21), siderophores, and $\mathrm{HCN}$ of the bacteria crack and deform the hyphae, which leads to altered cell structure and functions due to vacuolation and protoplast leakage (Ben-Khedher et al., 2015b; Han et al., 2015; Narendra-Babu et al., 2015). Bacterially synthesized antifungal peptides, such as iturin, fengycin, mixirin, pumilacidin, surfactin, and a novel cyclic peptide with a molecular weight of 852.4 $\mathrm{Da}$, are involved in the destruction of the pathogenic fungi in rhizospheres (Han et al., 2015; Yamamoto et al., 2015; Figure 1). Bacillus spp. mitigate pathogen-induced biotic stress via physiological changes (Table 2) in the photosynthetic and respiratory pathways and the regulation of carbohydrate, phenylpropanoid and $\mathrm{N}$ metabolism and defense-related proteins in diseased plants (Jain et al., 2015). Gene expression patterns in plants are also altered during infection by pathogenic fungi, and a number of dependent genes are activated to protect the plant from biotic stresses. The expression of genes encoding $\beta-1,3-$ glucanase $(P R-2)$, chitinase $(P R-3$ and $P R-4)$, peroxidase $(P R-$ 9 ), lipid transfer protein ( $P R-14)$, metallothionein-like protein (LfMT1), oxalate oxidase (LpOXO4), lipoxygenase (LOX), and a putative defensin $(L p T H b)$ are upregulated, whereas the putative glycine-rich protein (LfGRP1) and PsbR protein of photosystem $2(L f P s b R)$ genes are downregulated in diseased plants treated with Bacillus spp. (Liu et al., 2010; Kim et al., 2015; Rahman et al., 2015). The gene expression of major antioxidants and defense enzymes, such as POD, PAL, SOD, CAT, and PPO, is also stimulated during Bacillus spp. treatment (Narendra-Babu et al., 2015; Yang et al., 2015). The higher levels of energy, metabolism and defense-related proteins in Bacillus-treated diseased plants induce systemic resistance (Sarosh et al., 2009). The stress-induced transcriptional changes in plants trigger the production of secondary metabolites and defense enzymes to reduce oxidative damage. Antagonistic Bacillus spp. reduce lipid peroxidation and increase antioxidant enzymes, such as APX, CAT, GR, GPX, POD, PPO, other defense enzymes, such as PAL, chitinase (EC 3.2.1.14), and $\beta$-1,3-glucanase (EC 3.2.1.39), and phenolic acids to alleviate the adverse effects of pathogenic infection (Solanki et al., 2012; Chowdappa et al., 2013; Jain et al., 2013). The activity of hormones in plant immunity is well documented, and in particular, the synthesis of SA and JA plays a major role in plant defense. The cross talk among hormones is a complex process that induces disease resistance. Chowdappa et al. (2013) and Kang et al. (2015b) proved that the plant growth-promoting hormones IAA and GA are increased in Bacillus-treated plants along with SA, while JA and ABA are decreased in pathogen-infected plants. However, the studies on beneficial effect of Bacillus spp. in plants against fungal diseases conclude that the detrimental effects due to fungal infection in plants can be mitigated during the inoculation of Bacillus spp. by reprogramming the activity of plant defense enzymes and hormones. Additional physiological and molecular studies are required to elucidate the bio-control mechanisms of Bacillus spp. against pathogenic fungi-induced disease in crops.

\section{Bacillus spp.-Plant Interactions for Viral and Nematode Disease Resistance}

The second largest group of plant diseases after fungi is caused by viruses. The most effective method of virus control has been accomplished by chemical treatments. The prolonged use of chemicals leads to deposits in soil and increases the drug resistance of plant pathogens (Zhao et al., 2017). Some of the Bacillus spp., produce the antiviral compounds against pathogen (Esawy et al., 2011). Very few studies have reported on the biocontrol effects of bacteria in preventing or resisting viral disease. The disease rate is reduced as a consequence of induced systemic resistance (ISR) by interaction with Bacillus spp., leading to enhanced plant growth during cucumber mosaic virus infection (Zhang et al., 2004). The biofilm formation and surfactin production from $B$. amyloliquefaciens plantarum defense the viral disease in plants by triggering ISR machinery (Chowdhury et al., 2015b). Similarly, Bacillus spp. induce systemic resistance against viral disease caused by tobacco mosaic virus by inhibiting viral coat protein synthesis and by increasing the expression of disease-resistant signaling genes (Coil and NPR1), defense genes (PR-1a and PR-1b) and cell wall expansin (NtEXP2 and NtEXP6) genes in plants (Wang, 2009). The NPRI and Coil genes regulate the ISR- and JA-dependent pathways, respectively (Xie et al., 1998; Mou et al., 2003), which indicates that Bacillus spp. application can prevent viral damage in plants. However, crops are also damaged by nematodes, which are plant parasites and are recognized as a severe threat to plant growth. Root-knot nematodes have been recorded as the most damaging parasite relative to other types of nematodes worldwide. The host range of this nematode covers nearly 5500 plant species (Trudgill and Blok, 2001). The application of a bacterial inoculation controls the nematode populations. For example, Bacillus spp. prevent root-knot nematode infection in crops and develop resistance by reducing gall and egg masses in plants (Adam et al., 2014). Antimicrobial peptides, bacteriocins synthesized from Bacillus spp. inhibit the growth of pathogenic nematodes (Chowdhury et al., 2015b). Liu et al. (2013) identified the PZN gene cluster in B. amyloliquefaciens, and revealed that 
these genes are responsible for nematicidal activity against nematodes. In addition, the secretion of crystal proteins (Cry5B and Cry6A) from Bacillus spp. controls the growth of freeliving (Caenorhabditis elegans) and plant-parasitic (Meloidogyne hapla) nematodes (Yu et al., 2015). Cry5B binds with glycolipids receptors, leading to intestinal damage in C. elegans. Moreover, Cry6A restricts the growth of nematodes by inhibiting egg hatch, motility and infection to host tissues (Kho et al., 2011; Yu et al., 2015). The documented results of Bacillus spp. against virus and nematode suggest that some of the metabolites synthesized from Bacillus spp. inhibit the viral and nematodes population and increase the plant resistance through the expression of defense genes.

\section{CONCLUSIONS}

Crop productivity is decreasing due to climatic changes, and human populations are increasing daily, which results in starvation problems in under-developed countries. Research is ongoing to enhance crop yields despite various unfavorable environmental conditions. Physical, chemical and biological methods are being used to address the biotic and abiotic stressinduced damage in plants. The mutualistic relationship between plants and microbes is well known, especially the interactions between plants and bacteria either from the soil or inside the plants that help to improve the plant health under adverse stress conditions. The plant-beneficial Bacillus spp. produce plant growth-promoting substances (hormones and solubilizing enzymes) to increase plant growth. During drought and with salinity and heavy metal accumulation in the soil as well as pathogen infection, crop productivity is reduced, but the association with Bacillus ssp. promotes crop yield via various metabolites. Some of the physiological alterations in plants during Bacillus spp. inoculation in stress environments slow plant aging. For example, the ethylene-suppressing enzyme (ACC

\section{REFERENCES}

Abdalla, M. Y. (2015). Biological control and induction of systemic resistance against cucumber fusarium wilt by plant growth promoting rhizo-organisms. Egypt. J. Biol. Pest Cont. 25, 407-413.

Adam, M., Heuer, H., and Hallmann, J. (2014). Bacterial antagonists of fungal pathogens also control root-knot nematodes by induced systemic resistance of tomato plants. PLoS ONE 9:e90402. doi: 10.1371/journal.pone.0090402

Ahmad, I., Akhtar, M. J., Zahir, Z. A., Naveed, M., Mitter, B., and Sessitsch, A. (2014). Cadmium-tolerant bacteria induce metal stress tolerance in cereals. Environ. Sci. Pollut. Res. 21, 11054-11065. doi: 10.1007/s11356-014-3010-9

Akram, W., Anjum, T., and Ali, B. (2016). Phenylacetic acid is ISR determinant produced by Bacillus fortis IAGS162, which involves extensive re-modulation in metabolomics of tomato to protect against fusarium wilt. Front. Plant Sci. 7:498. doi: 10.3389/fpls.2016.00498

Al-Karaki, G. N. (2006). Nursery inoculation of tomato with arbuscular mycorrhizal fungi and subsequent performance under irrigation with saline water. Sci. Hortic. 109, 1-7. doi: 10.1016/j.scienta.2006.02.019

Almoneafy, A. A., Ojaghian, M. R., Xu, S., Ibrahim, M., Xie, G., Shi, Y., et al. (2013). Synergistic effect of acetyl salicylic acid and DL-Beta- aminobutyric acid on biocontrol efficacy of Bacillus strains against tomato bacterial wilt. Trop. Plant Pathol. 38, 102-113. doi: 10.1590/S1982-567620130002 00003 deaminase) synthesized by Bacillus spp. mitigates the detrimental effects of abiotic and biotic stress in plants by delaying senescence. Exopolysaccharide production by Bacillus spp. has been frequently reported to reduce sodium ion transport and regulate plant nutrient uptake during salinity stress. Additionally, the lipopeptides and toxic substances secreted from Bacillus spp. prevent pathogen growth and reduce disease occurrence in crops. The plant growth-promoting activities of Bacillus spp. have been well-documented as evidenced by increased growth of roots, shoots, and leaves as well as enhanced yields. However, very few studies have been conducted regarding the physiological and molecular aspects of these processes. Some of these studies have revealed that Bacillus spp. regulate nutrient uptake, water transport, and antioxidant, pigment, hormone and stress-responsive genes and proteins in plants leading to tolerance under adverse environmental conditions. This review concludes that Bacillus spp. are biological organisms that can potentially induce stress tolerance in plants, and more genomics, proteomics and metabolomics studies are required to elucidate the mechanism of Bacillus-plant interactions for biotic and abiotic stress management in crops.

\section{AUTHOR CONTRIBUTIONS}

$\mathrm{RR}, \mathrm{AH}$ and EA collected the research article information and wrote and revised the article together in a parallel manner. All the authors approved the final version of this manuscript.

\section{ACKNOWLEDGMENTS}

The authors would like to extend their sincere appreciation to the College of Science and College of Food \& Agricultural Sciences at King Saud University, Riyadh, Saudi Arabia. Additionally, the authors would like to extend their sincere appreciation to Yeungnam University, Gyeongsan, South Korea.
Andersson, I., and Backlund, A. (2008). Structure and function of rubisco. Plant Physiol. Biochem. 46, 275-291. doi: 10.1016/j.plaphy.2008.01.001

Arkhipova, T. N., Veselov, S. U., Melentiev, A. I., Martynenko, E. V., and Kudoyarova, G. R. (2005). Ability of bacterium Bacillus subtilis to produce cytokinins and to influence the growth and endogenous hormone content of lettuce plants. Plant Soil. 272, 201-209. doi: 10.1007/s11104-004-5047-x

Armada, E., Azcon, R., Lopez-Castillo, O. M., Calvo-Polanco, M., and RuizLozano, J. M. (2015). Autochthonous arbuscular mycorrhizal fungi and Bacillus thuringiensis from a degraded Mediterranean area can be used to improve physiological traits and performance of a plant of agronomic interest under drought conditions. Plant Physiol. Biochem. 90, 64-74. doi: 10.1016/j.plaphy.2015.03.004

Armada, E., Roldan, A., and Azcon, R. (2014). Differential activity of autochthonous bacteria in controlling drought stress in native lavandula and salvia plants species under drought conditions in natural arid soil. Microb. Ecol. 67, 410-420. doi: 10.1007/s00248-013-0326-9

Arrizubieta, M., Simon, O., Torres-Vila, L. M., Figueiredo, E., Mendiola, J., Mexia, A., et al. (2016). Insecticidal efficacy and persistence of a co-occluded binary mixture of Helicoverpa armigera nucleopolyhedrovirus (HearNPV) variants in protected and field-grown tomato crops on the Iberian Peninsula. Pest Manag. Sci. 72, 660-670. doi: 10.1002/ps.4035

Arthur, E., Moldrup, P., Holmstrup, M., Schjonning, P., Winding, A., Mayer, P., et al. (2012). Soil microbial and physical properties and their relations 
along a steep copper gradient. Agricult. Ecosys. Environ. 159, 9-18. doi: 10.1016/j.agee.2012.06.021

Ashraf, M. A., Hussain, I., Rasheed, R., Iqbal, M., Riaz, M., and Arif, M. S. (2017). Advances in microbe-assisted reclamation of heavy metal contaminated soils over the last decade: a review. J. Environ. Manag. 198, 132-143. doi: 10.1016/j.jenvman.2017.04.060

Ashraf, M., Hasnain, S., Berge, O., and Mahmood, T. (2004). Inoculating wheat seedlings with exopolysaccharide-producing bacteria restricts sodium uptake and stimulates plant growth under salt stress. Biol. Fertil. Soils 40, 157-162. doi: 10.1007/s00374-004-0766-y

Asif, M. H., Trivedi, P. K., Misra, P., and Nath, P. (2009). Prolyl-4-hydroxylase (AtP4H1) mediates and mimics low oxygen response in Arabidopsis thaliana. Funct. Integr. Genomics 9, 525-535. doi: 10.1007/s10142-009-0118-y

Aydi-Ben-Abdallah, R., Jabnoun-Khiareddine, H., Nefzi, A., Mokni-Tlili, S., and Daami-Remadi, M. (2016). Biocontrol of fusarium wilt and growth promotion of tomato plants using endophytic bacteria isolated from Solanum elaeagnifolium stems. J. Phytopathol. 164, 811-824. doi: 10.1111/jph.12501

Barker, A. V., Maynard, D. N., and Mills, H. A. (1974). Variations in nitrate accumulation among spinach cultivars. J. Am. Soc. Horticult. Sci. 99, 32-134.

Barnawal, D., Maji, D., Bharti, N., Chanotiya, C. S., and Kalra, A. (2013). ACC deaminase-containing Bacillus subtilis reduces stress ethylene-induced damage and improves mycorrhizal colonization and rhizobial nodulation in Trigonella foenum-graecum under drought stress. J. Plant Growth Regul. 32, 809-822. doi: 10.1007/s00344-013-9347-3

Beauregard, P. B., Chai, Y., Vlamakis, H., Losick, R., and Kolter, R. (2013). Bacillus subtilis biofilm induction by plant polysaccharides. Proc. Natl. Acad. Sci. U.S.A. 110, E1621-E1630. doi: 10.1073/pnas.1218984110

Benfarhat-Touzri, D., Amira, A., Ben, khedher, S., Ben, Givaudan, A., Jaoua, S., and Tounsi, S. (2014). Combinatorial effect of Bacillus thuringiensis kurstaki and Photorhabdus luminescens against Spodoptera littoralis (Lepidoptera: noctuidae). J. Basic Microbiol. 54, 1160-1165. doi: 10.1002/jobm.201300142

Ben-Khedher, S., Boukedi, H., Kilani-Feki, O., Chaib, I., Laarif, A., AbdelkefiMesrati, L., et al. (2015a). Bacillus amyloliquefaciens AG1 biosurfactant: putative receptor diversity and histopathological effects on Tuta absoluta midgut. J. Invertebr. Pathol. 132, 42-47. doi: 10.1016/j.jip.2015.08.010

Ben-Khedher, S., Kilani-Feki, O., Dammak, M., Jabnoun-Khiareddine, H., DaamiRemadi, M., and Tounsi, S. (2015b). Efficacy of Bacillus subtilis V26 as a biological control agent against Rhizoctonia solani on potato. C. R. Biol. 338, 784-792. doi: 10.1016/j.crvi.2015.09.005

Berlitz, D. L., de-Azambuja, A. O., Sebben, A., de-Oliveira, J. V., and Fiuza, L. M. (2012). Mortality of Oryzophagus oryzae (costa Lima, 1936) (coleoptera: curculionidae) and spodoptera frugiperda (J E Smith, 1797) (Lepidoptera: noctuidae) larvae exposed to Bacillus thuringiensis and extracts of melia azedarach. Brazilian Arch. Biol. Technol. 55, 725-731. doi: 10.1590/S1516-89132012000500012

Bidondo, L. F., Bompadre, J., Pergola, M., Silvani, V., Colombo, R., Bracamonte, F., et al. (2012). Differential interaction between two Glomus intraradices strains and a phosphate solubilizing bacterium in maize rhizosphere. Pedobiologia 55, 227-232. doi: 10.1016/j.pedobi.2012.04.001

Boomsma, C. R., and Vyn, T. J. (2008). Maize drought tolerance: potential improvements through arbuscular mycorrhizal symbiosis?. Field Crops Res. 108, 14-31. doi: 10.1016/j.fcr.2008.03.002

Bosecker, K. (1997). Bioleaching: metal solubilization by microorganisms. FEMS Microbiol. Rev. 20, 591-604. doi: 10.1111/j.1574-6976.1997.tb00340.x

Boukedi, H., Sellami, S., Ktari, S., Belguith-Ben-Hassan, N., Sellami-Boudawara, T., Tounsi, S., et al. (2016). Isolation and characterization of a new Bacillus thuringiensis strain with a promising toxicity against Lepidopteran pests. Microbiol. Res. 186-187, 9-15. doi: 10.1016/j.micres.2016.02.004

Brannen, P., and Kenney, D. (1997). Kodiak-A successful biological-con- trol product for suppression of soil-borne plant pathogens of cotton. J. Ind. Microbiol. Biotechnol. 19, 169-171. doi: 10.1038/sj.jim.2900439

Brownbridge, M. (2001). Greenhouse trials of new Bacillus thuringiensis isolates for control of chilo partellus larvae in sorghum. Phytoparasitica 29, 292-298. doi: 10.1007/BF02981845

Brunetti, G., Farrag, K., Soler-Rovira, P., Ferrara, M., Nigro, F., and Senesi, N. (2012). The effect of compost and Bacillus licheniformis on the phytoextraction of $\mathrm{Cr}, \mathrm{Cu}, \mathrm{Pb}$ and $\mathrm{Zn}$ by three brassicaceae species from contaminated soils in the Apulia region, Southern Italy. Geoderma 170, 322-330. doi: 10.1016/j.geoderma.2011.11.029

Cakmak, I. (2005). The role of potassium in alleviating detrimental effects of abiotic stresses in plants. J. Plant Nutr. Soil Sci. 168, 521-530. doi: 10.1002/jpln.200420485

Castillo, P., Escalante, M., Gallardo, M., Alemano, S., and Abdala, G. (2013). Effects of bacterial single inoculation and co-inoculation on growth and phytohormone production of sunflower seedlings under water stress. Acta Physiol. Plant. 35, 2299-2309. doi: 10.1007/s11738-013-1267-0

Cawoy, H., Bettiol, W., Fickers, P., and Ongena, M. (2011). "Bacillus-based biological control of plant diseases," in Pesticides in the Modern World Pesticides Use and Management, ed Stoytcheva (InTech Academic Press), 273-302.

Chakraborty, U., Chakraborty, B. N., Chakraborty, A. P., and Dey, P. L. (2013). Water stress amelioration and plant growth promotion in wheat plants by osmotic stress tolerant bacteria. World J. Microbiol. Biotechnol. 29, 789-803. doi: 10.1007/s11274-012-1234-8

Chen, Y., Yan, F., Chai, Y., Liu, H., Kolter, R., Losick, R., et al. (2013). Biocontrol of tomato wilt disease by Bacillus subtilis isolates from natural environments depends on conserved genes mediating biofilm formation. Environ. Microbiol. 15, 848-864. doi: 10.1111/j.1462-2920.2012.02860.x

Chithrashree, A. C., Udayashankar, S., Chandra-Nayaka, S., Reddy, M. S., and Srinivas, C. (2011). Plant growth-promoting rhizobacteria mediate induced systemic resistance in rice against bacterial leaf blight caused by Xanthomonas oryzae pv. oryzae. Biol. Control 59, 114-122. doi: 10.1016/j.biocontrol.2011.06.010

Choudhary, D. K. (2011). Plant growth promotion (PGP) activities and molecular characterization of rhizobacterial strains isolated from soybean (Glycine max L. Merril) plants against charcoal rot pathogen, Macrophomina phaseolina. Biotechnol. Lett. 33, 2287-2295. doi: 10.1007/s10529-011-0699-0

Choudhary, D. K., and Johri, B. N. (2009). Interactions of Bacillus spp. and plants with special reference to induced systemic resistance (ISR). Microbiol. Res. 164, 493-513. doi: 10.1016/j.micres.2008.08.007

Chowdappa, P., Mohan-Kumar, S. P., Jyothi-Lakshmi, M., and Upreti, K. K. (2013). Growth stimulation and induction of systemic resistance in tomato against early and late blight by Bacillus subtilis OTPB1 or Trichoderma harzianum OTPB3. Biol. Control. 65, 109-117. doi: 10.1016/j.biocontrol.2012.11.009

Chowdhury, S. P., Hartmann, A., Gao, X., and Borriss, R. (2015b). Biocontrol mechanism by root-associated Bacillus amyloliquefaciens FZB42-a review. Front. Microbiol. 6:780. doi: 10.3389/fmicb.2015.00780

Chowdhury, S. P., Uhl, J., Grosch, R., Alqueres, S., Pittroff, S., Dietel, K., et al. (2015a). Cyclic lipopeptides of Bacillus amyloliquefaciens subsp. plantarum colonizing the lettuce rhizosphere enhance plant defence responses towards the bottom rot pathogen Rhizoctonia solani. Mol. Plant Microb. Interact. 28, 17-18. doi: 10.1094/MPMI-03-15-0066-R

Davletova, S., Rizhsky, L., Liang, H., Shengqiang, Z., Oliver, D. J., Coutu, J., et al. (2005). Cyto-solic ascorbate peroxidase 1 is a central component of the reactive oxygen gene network of Arabidopsis. Plant Cell. 17, 268-281. doi: $10.1105 /$ tpc. 104.026971

De-Willigen, P. (1986). "Supply of soil nitrogen to the plant during the growing season," in Fundamental, Ecological and Agricultural Aspects of Nitrogen Metabolism in Higher Plants, eds H. Lambers, J. J. Neeteson, and I. Stulen (Dordrecht: Martinus Nijhoff), 417-432.

Dihazi, A., Jaiti, F., Taktak, W., Kilani-Feki, O., Jaoua, S., Driouich, A., et al. (2012). Use of two bacteria for biological control of bayoud disease caused by Fusarium oxysporum in date palm (Phoenix dactylifera L) seedlings. Plant Physiol. Biochem. 55, 7-15. doi: 10.1016/j.plaphy.2012.03.003

Ding, Y., Wang, J., Liu, Y., and Chen, S. (2005). Isolation and identification of nitrogen-fixing bacilli from plant rhizospheres in Beijing region. J. Appl. Microbiol. 99, 1271-1281. doi: 10.1111/j.1365-2672.2005.02738.x

Dursun, A., Ekinci, M., and Donmez, M. F. (2010). Effects of foliar application of plant growth promoting bacterium on chemical contents, yield and growth of tomato (Lycopersicon esculentum L.) and cucumber (Cucumis sativus L.). Pak. J. Bot. 42, 3349-3356.

Egamberdieva, D., Hashem, A., and Abd_Allah, E. F. (2014). "Biological control of fungal disease by rhizobacteria under saline soil conditions, in Emerging Technologies and Management of Crop Stress Tolerance, Vol. 2, Ed P. Ahmad 
(Cambridge, MA: A sustainable approach. Academic Press, Cambridge), 161-172.

Elshakh, A. S. A., Anjum, S. I., Qiu, W., Almoneafy, A. A., Li, W., Yang, Z., et al. (2016). Controlling and defence-related mechanisms of Bacillus strains against bacterial leaf blight of rice. J. Phytopathol. 164, 534-546. doi: 10.1111/jph.12479

El-Tayeb, M. A. (2005). Response of barley grains to the interactive effect of salinity and salicylic acid. Plant Growth Regul. 45, 215-224. doi: $10.1007 /$ s10725-005-4928-1

Esawy, M. A., Ahmed, E. F., Helmy, W. A., Mansour, N. M., El-Senousy, W. M., and El-Safty, M. M. (2011). Production of levansucrase from novel honey Bacillus subtilis isolates capable of producing antiviral levans. Carbohydr. Polym. 86, 823-830. doi: 10.1016/j.carbpol.2011.05.035

Feng, D., Chen, Z., Wang, Z., Zhang, C., He, K., and Guo, S. (2015). Domain III of Bacillus thuringiensis Crylle toxin plays an important role in binding to peritrophic membrane of Asian corn borer. PLOS ONE 10:e0136430. doi: 10.1371 /journal.pone. 0136430

Forgac, M. (2007). Vacuolar ATPases: rotary proton pumps in physiology and pathophysiology. Nat. Rev. Mol. Cell Biol. 8, 917-929. doi: 10.1038/nrm2272

Fousia, S., Paplomatas, E. J., and Tjamos, S. E. (2016). Bacillus subtilis QST 713 confers protection to tomato plants against Pseudomonas syringae pv tomato and induces plant defence-related genes. J. Phytopathol. 164, 264-270. doi: 10.1111/jph.12455

Fritz, R. R., Hodgins, D. S., and Abell, C. W. (1976). Phenylalanine ammonia-lyase. induction and purification from yeast and clearance in mammals. J. Biol. Chem. 251, 4646-4650.

Gadhave, K. R., and Gange, A. C. (2016). Plant-associated Bacillus spp. alter lifehistory traits of the specialist insect Brevicoryne brassicae L. Agric. For. Entomol. 18, 35-42. doi: 10.1111/afe.12131

Gagne-Bourque, F., Bertrand, A., Claessens, A., Aliferis, K. A., and Jabaji, S. (2016). Alleviation of drought stress and metabolic changes in timothy (Phleum pratense L.) colonized with Bacillus subtilis B26. Front. Plant Sci. 7:584. doi: $10.3389 /$ fpls.2016.00584

Garcia-Fraile, P., Menendez, E., and Rivas, R. (2015). Role of bacterial biofertilizers in agriculture and forestry. AIMS Bioeng. 2, 183-205. doi: 10.3934/bioeng.2015.3.183

Gassmann, W., Rubio, F., and Schroeder, J. I. (1996). Alkali cation selectivity of the wheat root high-affinity potassium transporter HKT1. Plant J. 10, 869-882. doi: 10.1046/j.1365-313X.1996.10050869.x

Girolami, V., Mazzon, L., Squartini, A., Mori, N., Marzaro, M., Di-Bernardo, et al. (2009). Translocation of neonicotinoid insecticides from coated seeds to seedling guttation drops: a novel way of intoxication for bees. J. Econ. Ecotoxicol. 102, 1808-1815. doi: 10.1603/029.102.0511

Glick, B. R. (1995). The enhancement of plant growth by free-living bacteria. Can. J. Microbiol. 41, 109-117. doi: 10.1139/m95-015

Glick, B. R. (2014). Bacteria with ACC deaminase can promote plant growth and help to feed the world. Microbiol. Res. 169, 30-39. doi: 10.1016/j.micres.2013.09.009

Goswami, D., Dhandhukia, P., Patel, P., and Thakker, J. N. (2014). Screening of PGPR from saline desert of Kutch: growth promotion in Arachis hypogea by Bacillus licheniformis A2. Microbiol. Res. 169, 66-75. doi: 10.1016/j.micres.2013.07.004

Groten, K., Dutilleul, C., Van-Heerden, P. D. R., Vanackera, H., Bernard, S., Finkemeier, I., et al. (2006). Redox regulation of peroxiredoxin and proteinases by ascorbate and thiols during pea root nodule senescence. FEBS Lett. 580, 1269-1276. doi: 10.1016/j.febslet.2006.01.043

Guo, L., Rasool, A., and Li, C. (2013). “Antifungal substrates of bacterial origin and plant disease management," in Bacteria in Agrobiology: Disease Management, , ed D. K. Maheshwari (Berlin; Heidelberg: Springer Verlag), 473-485.

Gururani, M. A., Upadhyaya, C. P., Baskar, V., Venkatesh, J., Nookaraju, A., and Park, S. W. (2013). Plant growth-promoting rhizobacteria enhance abiotic stress tolerance in Solanum tuberosum through inducing changes in the expression of ROS-scavenging enzymes and improved photosynthetic performance. J. Plant Growth Regul. 32, 245-258. doi: 10.1007/s00344-012-9292-6

Haas, D., and Defago, G. (2005). Biological control of soil-borne pathogens by fluorescent pseudomonads. Nat. Rev. Microbiol. 3, 307-319. doi: $10.1038 /$ nrmicro1129
Han, Q. Q., Lu, X. P., Bai, J. P., Qiao, Y., Pare, P. W., Wang, S. M., Zhang, J. L., et al. (2014). Beneficial soil bacterium Bacillus subtilis (GB03) augments salt tolerance of white clover. Front. Plant Sci. 5:525. doi: 10.3389/fpls.2014.00525

Han, Y., Zhang, B., Shen, Q., You, C., Yu, Y., Li, P., et al. (2015). Purification and identification of two antifungal cyclic peptides produced by Bacillus amyloliquefaciens L-H15. Appl. Biochem. Biotechnol. 176, 2202-2212. doi: 10.1007/s12010-015-1708-x

Hashem, A., Abd_Allah, E. F., Alqarawi, A. A., AL-Huqail, A. A., Alshalawi, S. R. M., Wirth, S., et al. (2015). Impact of plant growth promoting Bacillus subtilis on growth and physiological parameters of Bassia indica (Indian bassia) grown udder salt stress. Pak. J. Bot. 47, 1735-1741.

Hashem, A., Abd_Allah, E. F., Alqarawi, A. A., Al-Huqail, A. A., and Shah, M. A. (2016b). Induction of osmoregulation and modulation of salt stress in Acacia gerrardii benth. by arbuscular mycorrhizal fungi and Bacillus subtilis (BERA 71). Bio. Med. Res. Int. 2016:6294098. doi: 10.1155/2016/6294098

Hashem, A., Abd_Allah, E. F., Alqarawi, A. A., Al-Huqail, A. A., Wirth, S., and Egamberdieva, D. (2016a). The Interaction between arbuscular mycorrhizal fungi and endophytic bacteria enhances plant growth of Acacia gerrardii under salt stress. Front. Microbiol. 7:1089. doi: 10.3389/fmicb.2016.01089

Hayat, R., Ali, S., Amara, U., Khalid, R., and Ahmed, I. (2010). Soil beneficial bacteria and their role in plant growth promotion: a review. Ann. Microbiol. 60, 579-598. doi: 10.1007/s13213-010-0117-1

Herrera-Medina, M. J., Steinkellner, S., Vierheilig, H., Bote, J. A. O., and Garrido, J. M. G. (2007). Abscisic acid determines arbuscule development and functionality in the tomato arbuscular mycorrhiza. New Phytol. 175, 554-564. doi: 10.1111/j.1469-8137.2007.02107.x

Hinarejos, E., Castellano, M., Rodrigo, I., Belles, J. M., Conejero, V., Lopez-Gresa, M. P., et al. (2016). Bacillus subtilis IAB/BS03 as a potential biological control agent. Eur. J. Plant Pathol. 146, 597-608. doi: 10.1007/s10658-016-0945-3

Honma, M., and Shimomura, T. (1978). Metabolism of 1-aminocyclopropane-1carboxylic acid. Agric. Biol. Chem. 43, 1825-1831.

Hu, N., Zheng, J. F., Ding, D. X., Liu, J., Yang, L. Q., Yin, J., et al. (2009). Metal pollution in Huayuan river in hunan province in China by manganese sulphate waste residue. Bull. Environ. Contamin. Toxicol. 83, 583-590. doi: 10.1007/s00128-009-9802-9

Huang, J., Wei, Z., Tan, S., Mei, X., Shen, Q., and Xu, Y. (2014). Suppression of bacterial wilt of tomato by bioorganic fertilizer made from the antibacterial compound producing strain Bacillus amyloliquefaciens HR62. J. Agric. Food Chem. 62, 10708-10716. doi: 10.1021/jf503136a

Huda, K. M. K., Banu, M. S. A., Garg, B., Tula, S., Tuteja, R., and Tuteja, N. (2013). OsACA6, a P-type IIB $\mathrm{Ca}^{2+}$ ATPase promotes salinity and drought stress tolerance in tobacco by ROS scavenging and enhancing the expression of stress-responsive genes. Plant J. 76, 997-1015. doi: 10.1111/tpj.12352

Hussey, R. S., and McGuire, J. M. (1987). "Interactions with other organisms," in Principles and Practice of Nematode Control in Crops, eds R. H. Brown and B. R. Kerry (Marrickville, NSW: Academic Press), 294-320.

Jain, A., Singh, A., Singh, S., and Singh, H. B. (2013). Microbial consortiuminduced changes in oxidative stress markers in pea plants challenged with Sclerotinia sclerotiorum. J. Plant Growth Regul. 32, 388-398. doi: 10.1007/s00344-012-9307-3

Jain, A., Singh, A., Singh, S., Singh, V., and Singh, H. B. (2015). Comparative proteomic analysis in pea treated with microbial consortia of beneficial microbes reveals changes in the protein network to enhance resistance against Sclerotinia sclerotiorum. J. Plant Physiol. 182, 79-94. doi: 10.1016/j.jplph.2015.05.004

Jain, S. M. (1998). "Plant biotechnology and mutagenesis for sustainable crop improvement," in Crop Improvement for Stress Tolerance, eds R. K. Behl, D. K. Singh and G. P. Lodhi (New Delhi: CCSHAU, Hissar and MMB), 218-232.

Jamil, M., Zeb, S., Anees, M., Roohi, A., Ahmed, I., ur-Rehman, S., et al. (2014). Role of Bacillus licheniformis in phytoremediation of nickel contaminated soil cultivated with rice. Int. J. Phytoremed. 16, 554-571. doi: 10.1080/15226514.2013.798621

Jeschke, W. D., and Wolf, O. (1988). External potassium is not required for root growth in saline conditions: experiments with Ricinus communis L. growth in a reciprocal split-root system. J. Exp. Bot. 39, 1149-1167. doi: $10.1093 / \mathrm{jxb} / 39.9 .1149$ 
Jha, Y., and Subramanian, R. B. (2012). Paddy physiology and enzymes level is regulated by rhizobacteria under saline stress. J. Appl. Bot. Food Qual. 173, 168-173.

Jha, Y., and Subramanian, R. B. (2014). PGPR regulate caspase-like activity, programmed cell death, and antioxidant enzyme activity in paddy under salinity. Physiol. Mol. Biol. Plants 20, 1-7. doi: 10.1007/s12298-014-0224-8

Jha, Y., Subramanian, R. B. (2015). Reduced cell death and improved cell membrane integrity in rice under salinity by root associated bacteria. Theor. Exp. Plant Physiol. 27, 227-235. doi: 10.1007/s40626-015-0047-1

Jia, M., Keutgen, N., Matsuhashi, S., Mitzuniwa, C., Ito, T., Fujimura, T., et al. (2001). Ion chromatographic analysis of selected free amino acids and cations to investigate the change of nitrogen metabolism by herbicide stress in soybean (Glycine max). J. Agric. Food Chem. 49, 276-280. doi: 10.1021/jf990344c

Jiang, C. H., Huang, Z. Y., Xie, P., Gu, C., Li, K., Wang, D. C., et al. (2016). Transcription factors WRKY70 and WRKY11 served as regulators in rhizobacterium Bacillus cereus AR156-induced systemic resistance to Pseudomonas syringae pv. tomato DC3000 in Arabidopsis. J. Exp. Bot. 67, 157-174. doi: 10.1093/jxb/erv445

Jiang, C. H., Wu, F., Yu, Z. Y., Xie, P., Ke, H. J., Li, H. W., et al. (2015). Study on screening and antagonistic mechanisms of Bacillus amyloliquefaciens 54 against bacterial fruit blotch (BFB) caused by Acidovorax avenae subsp. citrulli. Microbiol. Res. 170, 95-104. doi: 10.1016/j.micres.2014.08.009

Jones, K. M., Kobayashi, H., Davies, B. W., Taga, M. E., and Walker, G. C. (2007). How rhizobial symbionts invade plants: the Sinorhizobium-Medicago model. Nat. Rev. Microbiol. 5, 619-633. doi: 10.1038/nrmicro1705

Jumali, S. S., Said, I. M., Ismail, I., and Zainal, Z. (2011). Genes induced by high concentration of salicylic acid in Mitragyna speciosa. Aust. J. Crop Sci. 5, 296-303.

Kakar, K. U., Ren, X. L., Nawaz, Z., Cui, Z. Q., Li, B., Xie, G. L., et al. (2016). A consortium of rhizobacterial strains and biochemical growth elicitors improve cold and drought stress tolerance in rice (Oryza sativa L.). Plant Biol. 18, 471-483. doi: $10.1111 /$ plb.12427

Kang, S. M., Radhakrishnan, R., Khan, A. L., Kim, M. J., Park, J. M., Kim, B. R., et al. (2014b). Gibberellin secreting rhizobacterium, Pseudomonas putida $\mathrm{H}-$ 2-3 modulates the hormonal and stress physiology of soybean to improve the plant growth under saline and drought conditions. Plant Physiol. Biochem. 84, 115-124. doi: 10.1016/j.plaphy.2014.09.001

Kang, S. M., Radhakrishnan, R., and Lee, I. J. (2015b). Bacillus amyloliquefaciens subsp. plantarum GR53, a potent biocontrol agent resists Rhizoctonia disease on Chinese cabbage through hormonal and antioxidants regulation. World J. Microbiol. Biotechnol. 31, 1517-1527. doi: 10.1007/s11274-015-1896-0

Kang, S. M., Radhakrishnan, R., Lee, K. E., You, Y. H., Ko, J. H., Kim, J. H., et al. (2015a). Mechanism of plant growth promotion elicited by Bacillus sp. LKE15 in oriental melon. Acta Agric. Scand. Sect. B Soil Plant Sci. 65, 637-647. doi: $10.1080 / 09064710.2015 .1040830$

Kang, S. M., Radhakrishnan, R., You, Y. H., Joo, G. J., Lee, I. J., Lee, K. E., et al. (2014a). Phosphate solubilizing Bacillus megaterium mj1212 regulates endogenous plant carbohydrates and amino acids contents to promote mustard plant growth. Indian J. Microbiol. 54, 427-433. doi: 10.1007/s12088-0140476-6

Kang, S. M., Radhakrishnan, R., You, Y. H., Khan, A. L., Lee, K. E., Lee, J. D., et al. (2015c). Enterobacter asburiae KE17 association regulates physiological changes and mitigates the toxic effects of heavy metals in soybean. Plant Biol. 17, 1013-1022. doi: 10.1111/plb.12341

Karlidag, H. (2013). Plant growth-promoting rhizobacteria mitigate deleterious effects of salt stress on strawberry plants (Fragaria Xananassa). Hortic. Sci. $48,563-567$.

Karmakar, R., and Kulshrestha, G. (2009). Persistance, metabolism and safety evaluation of thiamethoxam in tomato crop. Pest Manag. Sci. 65, 931-937. doi: 10.1002/ps.1776

Kasim, W. A., Osman, M. E., Omar, M. N., Abd-El-Daim, I. A., Bejai, S., and Meijer, J. (2013). Control of drought stress in wheat using plant-growth-promoting bacteria. J. Plant Growth Regul. 32, 122-130. doi: 10.1007/s00344-012-9283-7

Khan, N., Mishra, A., Chauhan, P. S., and Nautiyal, C. S. (2011). Induction of Paenibacillus lentimorbus biofilm by sodium alginate and $\mathrm{CaCl}_{2}$ alleviates drought stress in chickpea. Ann. Appl. Biol. 159, 372-386. doi: 10.1111/j.1744-7348.2011.00502.x
Kho, M. F., Bellier, A., Balasubramani, V., Hu, Y., Hsu, W., NielsenLeRoux, C., et al. (2011). The pore-forming protein Cry5B elicits the pathogenicity of Bacillus sp. against Caenorhabditis elegans. PLoS ONE 6:e29122. doi: 10.1371/journal.pone.0029122

Kilian, M., Steiner, U., Krebs, B., Junge, H., Schmiedeknecht, G., and Hain, R. (2000). FZB24 ${ }^{\circledR}$ Bacillus subtilis - mode of action of a microbial agent enhancing plant vitality. Pflanzenschutz Nachr. Bayer. 1, 72-93.

Kim, J. S., Lee, J., Lee, C. H., Woo, S. Y., Kang, H., Seo, S. G., et al. (2015). Activation of pathogenesis-related genes by the rhizobacterium, Bacillus sp. JS, which induces systemic resistance in tobacco plants. Plant Pathol. J. 31, 195-201. doi: 10.5423/PPJ.NT.11.2014.0122

Kleinwechter, U., Gastelo, M., Ritchie, J., Nelson, G., and Asseng, S. (2016). Simulating cultivar variations in potato yields for contrasting environments. Agric. Syst.. 145, 51-63. doi: 10.1016/j.agsy.2016.02.011

Koag, M. C., Fenton, R. D., Wilkens, S., and Close, T. J. (2003). The binding of maize DHN1 to lipid vesicles. gain of structure and lipid specificity. Plant Physiol. 131, 309-316. doi: 10.1104/pp.011171

Kosova, A. A., Khodyreva, S. N., and Lavrik, O. I. (2017). Role of glyceraldehyde3-phosphate dehydrogenase (GAPDH) in DNA Repair. Biochem. 82, 643-654. doi: 10.1134/S0006297917060013

Krid, S., Triki, M. A., Gargouri, A., and Rhouma, A. (2012). Biocontrol of olive knot disease by Bacillus subtilis isolated from olive leaves. Ann. Microbiol. 62, 149-154. doi: 10.1007/s13213-011-0239-0

Kuan, K. B., Othman, R., Rahim, K. A., and Shamsuddin, Z. H. (2016). Plant growth-promoting rhizobacteria inoculation to enhance vegetative growth, nitrogen fixation and nitrogen remobilisation of maize under greenhouse conditions. PLoS ONE 11:e0152478. doi: 10.1371/journal.pone.0152478

Kurabachew, H., and Wydra, K. (2014). Induction of systemic resistance and defense-related enzymes after elicitation of resistance by rhizobacteria and silicon application against Ralstonia solanacearum in tomato (Solanum lycopersicum). Crop Prot. 57, 1-7. doi: 10.1016/j.cropro.2013. 10.021

Lata, C., and Prasad, M. (2011). Role of DREBs in regulation of abiotic stress responses in plants J. Exp. Bot. 62, 4731-4748. doi: 10.1093/jxb/err210

Leung, J., and Giraudat, J. (1998). Abscisic acid signal transduction. Annu. Rev. Plant Physiol. Plant Mol. Biol. 49, 199-222. doi: 10.1146/annurev.arplant.49.1.199

Li, C., Sun, B., Li, Y., Liu, C., Wu, X., Zhang, D., et al. (2016). Numerous genetic loci identified for drought tolerance in the maize nested association mapping populations. BMC Genomic. 17:894. doi: 10.1186/s12864-016-3170-8

Lim, J. H., and Kim, S. D. (2013). Induction of drought stress resistance by multifunctional PGPR Bacillus licheniformis K11 in pepper. Plant Pathol. J. 29, 201-208. doi: 10.5423/PPJ.SI.02.2013.0021

Liu, Y. H., Huang, C. J., and Chen, C. Y. (2010). Identification and transcriptional analysis of genes involved in Bacillus cereus-induced systemic resistance in Lilium. Biologia Plant. 54, 697-702. doi: 10.1007/s10535-0100123-y

Liu, Z., Budiharjo, A., Wang, P., Shi, H., Fang, J., Borriss, R., et al. (2013). The highly modified microcin peptide plantazolicin is associated with nematicidal activity of Bacillus amyloliquefaciens FZB42. Appl. Microbiol. Biotechnol. 97, 10081-10090. doi: 10.1007/s00253-013-5247-5

Loutfy, N., El-Tayeb, M. A., Hassanen, A. M., Moustafa, M. F. M., Sakuma, Y., and Inouhe, M. (2012). Changes in the water status and osmotic solute contents in response to drought and salicylic acid treatments in four different cultivars of wheat (Triticum aestivum). J. Plant Res. 125, 173-184. doi: 10.1007/s10265-011-0419-9

Lu, S., Su, W., Li, H., and Guo, Z. (2009). Abscisic acid improves osmotic tolerance of triploid Bermuda grass and involves $\mathrm{H}_{2} \mathrm{O}_{2}$ and $\mathrm{NO}$ induced antioxidant enzyme activities. Plant Physiol. Biochem. 47, 132-138. doi: 10.1016/j.plaphy.2008.10.006

Lyngwi, N. A., and Joshi, S. R. (2014). "Economically important Bacillus and related genera: a mini review. in Biology of Useful Plants and Microbes. ed A. Sen (New Delhi: Narosa Publishing House), 33-43.

Ma, Y., Rajkumar, M., and Freitas, H. (2009). Inoculation of plant growthpromoting bacterium Achromobacter xylosoxidans strain Ax10 for the improvement of copper phytoextraction by Brassica juncea. J. Environ. Manag. 90, 831-837. doi: 10.1016/j.jenvman.2008.01.014 
Maget-Dana, R., and Peypoux, F. (1994). Iturins, a special class ofporeforming lipopeptides: biological and physicochemical properties. Toxicology 87 , 151-174. doi: 10.1016/0300-483X(94)90159-7

Maget-Dana, R., and Ptak, M. (1995). Interactions of surfactin with membrane models. Biophys. J. 68, 1937-1943. doi: 10.1016/S0006-3495(95) 80370-X

Malekzadeh, E., Alikhani, H. A., Savaghebi-Firoozabadi, G. R., and Zarei, M. (2012). Bioremediation of cadmium-contaminated soil through cultivation of maize inoculated with plant growth-promoting rhizobacteria. Bioremediat. J. 16, 204-211. doi: 10.1080/10889868.2012.703258

Martin, W., Hoffmeister, M., Rotte, C., and Henze, K. (2001). An overview of endosymbiotic models for the origins of eukaryotes, their ATPproducing organelles (mitochondria and hydrogenosomes) and their heterotrophic lifestyle. Biol. Chem. 382, 1521-1539. doi: 10.1515/BC. 2001.187

Marulanda, A., Barea, J. M., and Azcon, R. (2009). Stimulation of plant growth and drought tolerance by native microorganisms (AM fungi and bacteria) from dry environments. Mechanisms related to bacterial effectiveness. J. Plant Growth Regul. 28, 115-124. doi: 10.1007/s00344-009-9079-6

Maurel, C., Verdoucq, L., Luu, D.-T., and Santoni, V. (2008). Plant aquaporins: membrane channels with multiple integrated functions. Annu. Rev. Plant Biol. 59, 595-624. doi: 10.1146/annurev.arplant.59.032607.092734

Miller, G., Suzuki, N., Ciftci-Yilmaz, S., and Mittler, R. (2010). Reactive oxygen species homeostasis and signalling during drought and salinity stresses. Plant Cell Environ. 33, 453-467. doi: 10.1111/j.1365-3040.2009.02041.x

Mnif, I., and Ghribi, D. (2015). Potential of bacterial derived biopesticides in pest management. Crop Prot. 77, 52-64. doi: 10.1016/j.cropro.2015.07.017

Mohamed, H. I., and Gomaa, E. Z. (2012). Effect of plant growth promoting Bacillus subtilis and Pseudomonas fluorescens on growth and pigment composition of radish plants (Raphanus sativus) under $\mathrm{NaCl}$ stress. Photosynthetica 50, 263-272. doi: 10.1007/s11099-012-0032-8

Mou, Z., Fan, W., and Dong, X. (2003). Inducers of plant systemic acquired resistance regulate NPR1 function through redox changes. Cell. 113: 815-826. doi: 10.1016/S0092-8674(03)00429-X

Munns, R., and Tester, M. (2008). Mechanisms of salinity tolerance. Annu. Rev. Plant Biol. 59, 651-681. doi: 10.1146/annurev.arplant.59.032607.092911

Myresiotis, C. K., Vryzas, Z., and Papadopoulou-Mourkidou, E. (2015). Effect of specific plant-growth-promoting rhizobacteria (PGPR) on growth and uptake of neonicotinoid insecticide thiamethoxam in corn (Zea mays L.) seedlings. Pest Manag. Sci. 71, 1258-1266. doi: 10.1002/ps.3919

Nadeem, S. M., Shaharoona, B., Arshad, M., and Crowley, D. E. (2012). Population density and functional diversity of plant growth promoting rhizobacteria associated with avocado trees in saline soils. Agric. Ecosyst. Environ. Appl. Soil Ecol. 62, 147-154. doi: 10.1016/j.apsoil.2012.08.005

Narasimhan, A., and Shivakumar, S. (2015). Evaluation of Bacillus subtilis (JN032305) biofungicide to control chilli anthracnose in pot controlled conditions. Biocontrol Sci. Technol. 25, 543-559. doi: 10.1080/09583157.2014.996737

Narendra-Babu, A., Jogaiah, S., Ito, S. I., Kestur-Nagaraj, A., and Tran, L. S. P. (2015). Improvement of growth, fruit weight and early blight disease protection of tomato plants by rhizosphere bacteria is correlated with their beneficial traits and induced biosynthesis of antioxidant peroxidase and polyphenol oxidase. Plant Sci. 231, 62-73. doi: 10.1016/j.plantsci.2014.11.006

Nautiyal, C. S., Srivastava, S., Chauhan, P. S., Seem, K., Mishra, A., and Sopory, S. K. (2013). Plant growth-promoting bacteria Bacillus amyloliquefaciens NBRISN13 modulates gene expression profile of leaf and rhizosphere community in rice during salt stress. Plant Physiol. Biochem. 66, 1-9. doi: 10.1016/j.plaphy.2013.01.020

Navon, A. (2000). Bacillus thuringiensis insecticides in crop protection - Reality and prospects. Crop Prot. 19, 669-676. doi: 10.1016/S0261-2194(00)00089-2

Ngugi, H., Dedej, S., Delaplane, K., Savelle, A., and Scherm, H. (2005). Efect of flower-applied Serenade biofungicide (Bacillus subtilis) on pollinationrelated variables in rabbit eye blueberry. Biol. Control. 33, 32-38. doi: 10.1016/j.biocontrol.2005.01.002

Pandey, S., Ghosh, P. K., Ghosh, S., De, T. K., and Maiti, T. K. (2013). Role of heavy metal resistant Ochrobactrum sp. and Bacillus spp. strains in bioremediation of a rice cultivar and their PGPR like activities. J. Microbiol. 51, 11-17. doi: $10.1007 /$ s12275-013-2330-7
Paramasiva, I., Krishnayya, P. V., War, A. R., and Sharma, H. C. (2014). Crop hosts and genotypic resistance influence the biological activity of Bacillus thuringiensis towards Helicoverpa armigera. Crop Prot. 64, 38-46. doi: 10.1016/j.cropro.2014.05.010

Porat, R., Pasentsis, K., Rozentzvieg, D., Gerasopoulos, D., Falarac, V., Samach, A., et al. (2004). Isolation of a dehydrin cDNA from orange and grapefruit citrus fruit that is specifically induced by the combination of heat followed by chilling temperatures. Physiol. Plant. 120, 256-264. doi: 10.1111/j.0031-9317.2004.0242.x

Porcel, R., Aroca, R., and Ruiz-Lozano, J. M. (2012). Salinity stress alleviation using arbuscular mycorrhizal fungi. A review. Agron. Sustain. Dev. 32, 181-200. doi: 10.1007/s13593-011-0029-x

Pourbabaee, A. A., Bahmani, E., Alikhani, H. A., and Emami, S. (2016). Promotion of wheat growth under salt stress by halotolerant bacteria containing ACC deaminase. J. Agric. Sci. Technol. 18, 855-864.

Qurashi, A. W., and Sabri, A. N. (2013). Osmolyte accumulation in moderately halophilic bacteria improves salt tolerance of chickpea. Pakist. J. Bot. 45, 1011-1016.

Radhakrishnan, R., Kang, S. M., Baek, I. Y., and Lee, I. J. (2014). Characterization of plant growth-promoting traits of Penicillium species against the effects of high soil salinity and root disease. J. Plant Interact. 9, 754-762. doi: 10.1080/17429145.2014.930524

Radhakrishnan, R., and Lee, I. J. (2013). Regulation of salicylic acid, jasmonic acid and fatty acids in cucumber (Cucumis sativus L.) by spermidine promotes plant growth against salt stress. Acta Physiol. Plant. 35, 3315-3322. doi: 10.1007/s11738-013-1364-0

Radhakrishnan, R., and Lee, I. J. (2014). Effect of low dose of spermidine on physiological changes in salt stressed cucumber plants. Russ. J. Plant Physiol. 61, 90-96. doi: 10.1134/S10214437140 10129

Radhakrishnan, R., and Lee, I. J. (2016). Gibberellins producing Bacillus methylotrophicus KE2 supports plant growth and enhances nutritional metabolites and food values of lettuce. Plant Physiol. Biochem. 109, 181-189. doi: 10.1016/j.plaphy.2016.09.018

Radhakrishnan, R., Shim, K. B., Lee, B. W., Hwang, C. D., Pae, S. B., Park, C. H., et al. (2013). IAA-producing Penicillium sp. NICS01 triggers plant growth and suppresses Fusarium sp.-induced oxidative stress in sesame (Sesamum indicum L.). J. Microbiol. Biotechnol. 23, 856-863. doi: 10.4014/jmb.1209. 09045

Rady, M. M. (2011). Effect of 24-epibrassinolide on growth, yield, antioxidant system and cadmium content of bean (Phaseolus vulgaris L.) plants under salinity and cadmium stress. Sci. Horticult. 129: 232-237. doi: 10.1016/j.scienta.2011.03.035

Rahman, A., Uddin, W., and Wenner, N. G. (2015). Induced systemic resistance responses in perennial ryegrass against Magnaporthe oryzae elicited by semipurified surfactin lipopeptides and live cells of Bacillus amyloliquefaciens. Mol. Plant Pathol. 16, 546-558. doi: 10.1111/mpp.12209

Riaz, S., Faisal, M., and Hasnain, S. (2010). Cicer arietinum growth promotion by Ochrobactrum intermedium and Bacillus cereus in the presence of $\mathrm{CrCl}_{3}$ and $\mathrm{K}_{2} \mathrm{CrO}_{4}$. Ann. Microbiol. 60, 729-733. doi: 10.1007/s13213-010-0123-3

Robinson, D. (2001). Root proliferation, nitrate inflow and their carbon costs during nitrogen capture by competing plants in patchy soil. Plant Soil. 232, 41-50. doi: 10.1023/A:1010377818094

Sandhya, V., Ali, S. Z., Grover, M., Reddy, G., and Bandi, V. (2011). Droughttolerant plant growth promoting Bacillus spp.: effect on growth, osmolytes, and antioxidant status of maize under drought stress. J. Plant Interact. 6, 1-14. doi: 10.1080/17429145.2010.535178

Sarosh, B. R., Danielsson, J., and Meijer, J. (2009). Transcript profiling of oilseed rape (Brassica napus) primed for biocontrol differentiate genes involved in microbial interactions with beneficial Bacillus amyloliquefaciens from pathogenic Botrytis cinerea. Plant Mol. Biol. 70, 31-45. doi: 10.1007/s11103-0099455-4

Schoffl, F., Prandl, R., and Reindl, A. (1998). Regulation of the heatshock response. Plant Physiol. 117, 1135-1141. doi: 10.1104/pp.117.4.1135

Shaul-Keinan, O., Gadkar, V., Ginzberg, I., Grunzweig, J. M., Chet, I., Elad, Y., et al. (2002). Hormone concentrations in tobacco roots change during arbuscular mycorrhizal colonization with Glomus intraradices. New Phytol. 154, 501-507. 
Sofia, H. J., Chen, G., Hetzler, B. G., Reyes-Spindola, J. F., and Miller, N. E. (2001). Radical, SAM, a novel protein superfamily linking unresolved steps in familiar biosynthetic pathways with radical mechanisms: functional characterization using new analysis and information visualization methods. Nucleic Acids Res. 29, 1097-1106. doi: 10.1093/nar/29.5.1097

Solanki, M. K., Robert, A. S., Singh, R. K., Kumar, S., Pandey, A. K., Srivastava, A. K., et al. (2012). Characterization of mycolytic enzymes of Bacillus strains and their bio-protection role against Rhizoctonia solani in tomato. Curr. Microbiol. 65, 330-336. doi: 10.1007/s00284-012-0160-1

Tanaka, Y., Matsuoka, M., Yamanoto, N., Ohashi, Y., Kano-Murakami, Y., and Ozeki, Y. (1989). Structure and characterization of a cDNA clone for phenylalanine ammonia-lyase from cut-injured roots of sweet potato. Plant Physiol. 90, 1403-1407. doi: 10.1104/pp.90.4.1403

Tandy, S., Schulin, R., and Nowack, B. (2006). The influence of EDDS on the uptake of heavy metals in hydroponically grown sunflowers. Chemosphere. 62, 1454-1463. doi: 10.1016/j.chemosphere.2005.06.005

Theodorou, M. E., Plaxton, W. C. (1993). Metabolic adaptations of plant respiration to nutritional phosphate deprivation. Plant Physiol. 101, 339-344. doi: 10.1104/pp.101.2.339

Timmusk, S., Kim, S. B., Nevo, S. E., Abd El-Daim, I. A., Ek, B., Bergquist, J., et al. (2015). Sfp-type PPTase inactivation promotes bacterial biofilm formation and ability to enhance wheat drought tolerance. Front. Microbiol. 6:387. doi: $10.3389 /$ fmicb. 2015.00387

Tiwari, S., Singh, P., Tiwari, R., Meena, K. K., Yandigeri, M., Singh, D. P., et al. (2011). Salt-tolerant rhizobacteria-mediated induced tolerance in wheat (Triticum aestivum) and chemical diversity in rhizosphere enhance plant growth. Biol. Fertil. Soils 47, 907-916. doi: 10.1007/s00374-011-0598-5

Tonelli, M. L., Taurian, T., Ibanez, F., Angelini, J., and Fabra, A. (2010). Selection and in vitro characterization of biocontrol agents with potential to protect peanut plants against fungal pathogens. J. Plant Pathol. 92, 73-82.

Trudgill, D. L., and Blok, V. C. (2001). Apomictic, polyphagous root-knot nematodes: exceptionally successful and damaging biotrophic root pathogens. Annu. Rev. Phytopathol. 39, 53-77. doi: 10.1146/annurev.phyto.39.1.53

Vachon, V., Laprade, R., and Schwartz, J. L. (2012). Current models of the mode of action of Bacillus thuringiensis insecticidal crystal proteins: a critical review. J. Invertebr. Pathol. 111, 1-12. doi: 10.1016/j.jip.2012.05.001

Vieira-Pires, R. S., Szollosi, A., and Morais-Cabral, J. H. (2013). The structure of the KtrAB potassium transporter. Nature 496, 323-327. doi: 10.1038/nature12055

Walker, E. L., and Connolly, E. L. (2008). Time to pump iron: iron-deficiencysignaling mechanisms of higher plants. Curr. Opin. Plant Biol. 11, 530-535. doi: 10.1016/j.pbi.2008.06.013

Wang, C. J., Yang, W., Wang, C., Gu, C., Niu, D. D., Liu, H. X., et al. (2012). Induction of drought tolerance in cucumber plants by a consortium of three plant growth-promoting rhizobacterium strains. PLoS ONE 7:e52565. doi: 10.1371/journal.pone.0052565

Wang, H., Xu, R., You, L., and Zhong, G. (2013). Characterization of Cu-tolerant bacteria and definition of their role in promotion of growth, $\mathrm{Cu}$ accumulation and reduction of $\mathrm{Cu}$ toxicity in Triticum aestivum L. Ecotoxicol. Environ. Saf. 94, 1-7. doi: 10.1016/j.ecoenv.2013.04.005

Wang, S. (2009). Molecular mechanism of plant growth promotion and induced systemic resistance to tobacco mosaic virus by Bacillus spp. J. Microbiol. Biotechnol. 19, 1250-1258. doi: 10.4014/jmb.0901.008

Wang, X., Xue, Y., Han, M., Bu, Y., Liu, C. (2014). The ecological roles of Bacillus thuringiensis within phyllosphere environments. Chemosphere 108: 258-264. doi: 10.1016/j.chemosphere.2014.01.050

Wani, P. A., and Khan, M. S. (2010). Bacillus species enhance growth parameters of chickpea (Cicer arietinum L.) in chromium stressed soils. Food Chem. Toxicol. 48, 3262-3267. doi: 10.1016/j.fct.2010.08.035

Wielkopolan, B., and Obrepalska-Steplowska, A. (2016). Three-way interaction among plants, bacteria, and coleopteran insects. Planta 244, 313-332. doi: 10.1007/s00425-016-2543-1

Xie, D. X., Feys, B. F., James, S., Nieto-Rostro, M., and Turner, J. G. (1998). Coil: an Arabidopsis gene required for jasmonate regulated defense and fertility. Science 280, 1091-1094. doi: 10.1126/science.280.5366.1091

Xie, S., Wu, H. J., Zang, H., Wu, L., Zhu, Q., and Gao, X. (2014). Plant growth promotion by spermidine-producing Bacillus subtilis OKB105. Mol. Plant Microbe Interact. 27, 655-663. doi: 10.1094/MPMI-01-14-0010-R
Xu, M., Sheng, J., Chen, L., Men, Y., Gan, L., Guo, S., et al. (2014). Bacterial community compositions of tomato (Lycopersicum esculentum Mill.) seeds and plant growth promoting activity of ACC deaminase producing Bacillus subtilis (HYT-12-1) on tomato seedlings. World J. Microbiol. Biotechnol. 30: 835-845. doi: 10.1007/s11274-013-1486-y

Xu, P., Jiang, L., Wu, J., Li, W., Fan,S., and Zhang, S. (2014). Isolation and characterization of a pathogenesis-related protein 10 gene (GmPR10) with induced expression in soybean (Glycine max) during infection with Phytophthora sojae. Mol. Biol. Rep. 41, 4899-4909. doi: 10.1007/s11033-014-3356-6

Yamamoto, S., Shiraishi, S., and Suzuki, S. (2015). Are cyclic lipopeptides produced by Bacillus amyloliquefaciens S13-3 responsible for the plant defence response in strawberry against Colletotrichum gloeosporioides?. Lett. Appl. Microbiol. 60, 379-386. doi: 10.1111/lam.12382

Yang, A., Akhtar, S. S., Iqbal, S., Amjad, M., Naveed, M., Zahir, Z. A., et al. (2016). Enhancing salt tolerance in quinoa by halotolerant bacterial inoculation. Funct. Plant Biol. 43, 632-642. doi: 10.1071/FP15265

Yang, R., Fan, X., Cai, X., and Hu, F. (2015). The inhibitory mechanisms by mixtures of two endophytic bacterial strains isolated from Ginkgo biloba against pepper phytophthora blight. Biol. Control 85, 59-67. doi: 10.1016/j.biocontrol.2014.09.013

Yi, H. S., Yang, J. W., and Ryu, C. M. (2013). ISR meets SAR outside: additive action of the endophyte Bacillus pumilus INR7 and the chemical inducer, benzothiadiazole, on induced resistance against bacterial spot in field-grown pepper. Front. Plant Sci. 4:122. doi: 10.3389/fpls.2013.00122

Yu, Z., Xiong, J., Zhou, Q., Luo, H., Hu, S., Xia, L., et al. (2015). The diverse nematicidal properties and biocontrol efficacy of Bacillus thuringiensis Cry6A against the root-knot nematode Meloidogyne hapla. J. Invertebr. Pathol. 125, 73-80. doi: 10.1016/j.jip.2014.12.011

Zawadzka, A. M., Abergel, R. J., Nichiporuk, R., Andersen, U. N., and Raymond, K. N. (2009). Siderophore-mediated iron acquisition systems in Bacillus cereus: identification of receptors for anthrax virulenceassociated petrobactin. Biochem. 48, 3645-3657. doi: 10.1021/bi8018674

Zebelo, S., Song, Y., Kloepper, J. W., and Fadamiro, H. (2016). Rhizobacteria activates $(+)-\beta$-cadinene synthase genes and induces systemic resistance in cotton against beet armyworm (Spodoptera exigua). Plant Cell Environ. 39, 935-943. doi: 10.1111/pce.12704

Zgallai, H., Steppe, K., and Lemeur, R. (2005). Photosynthetic, physiological and biochemical responses of tomato plants to polyethylene glycol-induced water deficit. J. Integr. Plant Biol. 47, 1470-1478. doi: 10.1111/j.1744-7909.2005.00193.x

Zhang, D., Liang, W., Yin, C., Zong, J., and Gu, F. (2010). OsC6, encoding a lipid transfer protein, is required for postmeiotic anther development in rice. Plant Physiol. 154, 149-162. doi: 10.1104/pp.110.158865

Zhang, S., Reddy, M. S., and Kloepper, J. W. (2004). Tobacco growth enhancement and blue mold disease protection by rhizobacteria: relationship between plant growth promotion and systemic disease protection by PGPR strain 90-166. Plant Soil. 262, 277-288. doi: 10.1023/B:PLSO.0000037048.26437.fa

Zhao, L., Feng, C., Wu, K., Chen, W., Chen, Y., Hao, X., et al. (2017). Advances and prospects in biogenic substances against plant virus: a review. Pest. Biochem. Physiol. 135, 15-26. doi: 10.1016/j.pestbp.2016.07.003

Zhu, S. Q., Chen, M. W., Ji, B. H., Jiao, D. M., Liang, J. S. (2011). Roles of xanthophylls and exogenous $\mathrm{ABA}$ in protection against $\mathrm{NaCl}$ induced photodamage in rice (Oryza sativa L) and cabbage (Brassica campestris). J. Exp. Bot. 62, 4617-4625. doi: 10.1093/jxb/err170

Conflict of Interest Statement: The authors declare that the research was conducted in the absence of any commercial or financial relationships that could be construed as a potential conflict of interest.

Copyright $(2017$ Radhakrishnan, Hashem and Abd_Allah. This is an open-access article distributed under the terms of the Creative Commons Attribution License (CC BY). The use, distribution or reproduction in other forums is permitted, provided the original author(s) or licensor are credited and that the original publication in this journal is cited, in accordance with accepted academic practice. No use, distribution or reproduction is permitted which does not comply with these terms. 